\title{
DIPLOLEPIS ROSAE (L.) (HYMENOPTERA: CYNIPIDAE): DEVELOPMENT, ECOLOGY AND GALLS IN THE BRNO REGION
}

\author{
Jaroslav Urban ${ }^{1}$ \\ ${ }^{1}$ Department of Forest Protection and Wildlife Management, Faculty of Forestry and Wood Technology, Mendel \\ University in Brno, Zemědělská 1, 61300 Brno, Czech Republic
}

\begin{abstract}
URBAN JAROSLAV. 2018. Diplolepis Rosae (L.) (Hymenoptera: Cynipidae): Development, Ecology and Galls in the Brno Region. Acta Universitatis Agriculturae et Silviculturae Mendelianae Brunensis, 66(4): 905-925.

The paper results from two years of studying development and formation of the galls of Diplolepis rosae (L.) on Rosa canina (L.) in the Brno region (Czech Republic). Following the extremely warm and dry growing season of $2015,70 \%$ of prepupae and $30 \%$ of grown-up $2^{\text {nd }}$ instar larvae hibernated. After the climatically milder growing period of 2016 , only $47 \%$ of prepupae and $53 \%$ of grown-up larvae hibernated. Pupae were recorded from mid-March to mid-July and imagoes occurred from April to July. The average percentage of males in the populations was $4.5 \%$. Eggs were found in the galls from May to July. Larvae of the $1^{\text {st }}$ and $2^{\text {nd }}$ instars were found in the galls from June to August and from July to October (or to next March), respectively. Average cranium width in the $1^{\text {st }}$ instar larvae increased during the growth of larvae from 0.25 to $0.35 \mathrm{~mm}$, i.e. by $38 \%$. Average cranium width in the $2^{\text {nd }}$ instar larvae was $0.55 \mathrm{~mm}$ and practically did not change during the growth of the larvae. $85.1 \%$ of galls were formed on budding leaves, $14.9 \%$ on flowers and fruits. The galls were growing most rapidly in June and July, and their growth ended in October when they reached average height and width of $40 \mathrm{~mm}$ and $47 \mathrm{~mm}$, respectively. They consisted of 1 to 20 (on average 7) \pm intergrown parts with 1 to 225 (on average 54) cells. $63.5 \%$ of them were localized along the sides of shoots and $36.5 \%$ were found on the shoot tips. The largest cells $(3.9 \times 3.1 \mathrm{~mm})$ were those with the completed development of gall wasp larvae. Cells inhabited by parasitoids were by $15.0 \%$ smaller and by $24.5 \%$ smaller were cells with dead gallwasp larvae due to natural reasons. As compared with the cells with the completed development of gall wasp, cells with the larvae of inquiline Periclistus brandtii (Ratz.) were by $43.6 \%$ shorter and by $50.6 \%$ narrower. The inquiline was found in $10 \%$ of galls and in $3.6 \%$ of cells. In 2015 , parasitoids inhabited on average $15.0 \%$ (in $201622.1 \%$ ) of cells. Approximately $50 \%$ of the population of D. rosae died in the galls during the preimaginal development.
\end{abstract}

Keywords: Diplolepis rosae, Cynipidae, hibernation, development, galls, inquiline Periclistus brandtii, mortality

\section{INTRODUCTION}

Gall wasp Diplolepis rosae (Linnaeus, 1758) (syn. Cynips rosae, Rhodites rosae, Diplolepis bedeguaris) is the most common representative of the genus Diplolepis Geoffroy, 1762. This cecidogenous genus, classified within the Diplolepini tribe, is represented in the Palaearctic region by approximately 16 species living exclusively on roses (Rosa spp.), on which they form species-specific galls. From ten European species (Kovalev, 1981) and

$\overline{1}$ The study was elaborated at Mendel University in Brno, Faculty of Forestry and Wood Technology 
six native species (Mikula, 1989), galls of D. rosae are most conspicuous and usually also most abundant. Biogeography, hosts, abundance, formation of galls and natural enemies of gall wasp are subjects of numerous studies some of which are older than 120 years. Recently in particular, many authors study the abundant inquiline species of Periclistus brandtii (Ratz.) (Cynipidae: Synergini) and an endosymbiotic bacteria from the family of Wolbachia Hert. (Rickettsiales).

Despite the above-mentioned facts, there are still unresolved questions remaining in the biology of D. rosae, which particularly relate to the causes of gall formation, course of the development of individual evolution stages (and instars), genetic structure of populations and specific relation to various hosts. The submitted paper deals with the development of $D$. rosae, the size of its galls, number and size of cells. The main objective of the study was to determine the course of the development of larvae and the number of their instars.

\section{Geographical distribution and host plants}

Diplolepis rosae is a Holarctic species widely spread in the northern temperate zone. In the Palaearctic region, it occurs from North Africa, across West, Central and South Europe, reaching up to the European part of the former USSR. It is reported from Asia Minor, Western Asia, Central Asia and Eastern-Palaearctic subregion. In 1868, it was introduced into North America along with its main European host plant, i.e. Rosa canina L. (Weld, 1926; Judd, 1959). Hosts are numerous wild Rosa spp., on the leaves, flowers and fruits of which the gall wasp creates specific and very conspicuous galls. According to the Rosa family, the species was given valid generic scientific designation and name nearly in all national languages. The occurrence of D. rosae in Europe and North America on ten Rosa spp. was mentioned already by Dalla Torre (1893). Kovalev (1981) reported D. rosae from Europe and Kazakhstan on Rosa canina L., R. arvensis Huds., R. pendulina L., R. micrantha Sm. and R. dumalis Bechst. According to Darboux and Houard (1901), the species occurs in Europe and in the Mediterranean subregion on twenty Rosa spp. As host plants, the authors consider among others R. canina L., R. agrestis Savi, R. arvensis Huds., R. dumalis Bechst., R. gallica L., R. glauca Pourr., R. inodora Fries., R. micrantha Sm., R. pimpinellifolia L. and R. rubiginosa L., which are known from the Czech Republic, too.

The centre of the occurrence of $D$. rosae is in Europe (Kieffer, 1914; Escherich, 1942; Gauss, 1982). In northern Europe, its occurrence is limited to southern Scandinavia (Vyržikovskaja, 1962; Stille, 1984). In southern Sweden, galls were found apart from on $R$. canina also on $R$. dumalis Bechst., $R$. rubiginosa L., R. villosa L., R. sherardii Dav. and R. glauca Pourr., but not on R. majalis Herrm. and R. rugosa Thunb. (Stille, 1984). In Great Britain and Ireland, galls were most frequently found on the wild $R$. canina (Redfern, 1997; Williams and Randolph, 2002; Ellis, 2004; O'Connor, 2004) and on R. glauca Pourr. (Bowdrey, 2007). The common occurrence of D. rosae on Rosa spp. in the open and its occasional occurrence on cultivated species are mentioned for example by Schröder (1967). Schröder (1967), Syrett (1990) and Herting (s. a.) consider D. rosae a species efficient in the biological control of Rosa rubiginosa L., widespread in New Zealand following the successful control of wild rabbit.

A number of studies on the occurrence and distribution of $D$. rosae originates from non-European countries. For example, Bayram, Ülgentürk and Toros (1998), Güçlü et al. (2008), and Katılmıs and Kiyak (2010) studied the species in Turkey. The most abundant species in that country is however D. fructorum (Rübs.), which is taken for the pest on Rosa spp. fruits in plantations. Together with D. mayri (Schl.), it was introduced into Iran (Farahbakhsh, 1961), where it was later studied (Shojai, 1998; Hesami et al., 2008). Gibson (1935) ranked it with the harmful species on Rosa spp. in Canada. According to Shorthouse (2001), it was introduced into Canada with its European host plants $R$. canina and $R$. rubiginosa and occurs there both on wild growing shrubs and on shrubs cultivated in gardens. The occurrence of D. rosae on R. canina L. and R. rubiginosa L. in the non-arctic region is reported e.g. by Judd (1959) and on $R$. rubiginosa L. by Ritchie and Peters (1981). Liu, Zhang and Xiao (2012) maintain that from North America it was introduced into China where it causes massive damage on $R$. sertata Rolfe $\times R$. rugosa Thunb. for example in the province of Gans.

Entomologists dealing with faunistical studies of cecidogenous insect species in the Czech Republic were E. Bayer in 1909-1922 and E. Baudyš in 1913-1966. Thanks to their numerous findings on many Rosa spp., the occurrence of D. rosae is relatively well mapped. Recently, faunistics of gall wasps in the Podyjí National Park was studied by Holý (2011), who found D. rosae on a majority of 25 surveyed localities.

\section{The current state of knowledge}

Fundamental data on D. rosae can be found in many entomological and nature conservation compendia (Kieffer, 1914; Escherich, 1942; Miller, 1956; Gauss, 1982; Sedlag et al., 1986 and others). Several researchers studied primarily its morphology and taxonomy (Dalla Torre and Kieffer, 1910; Ritchie and Peters, 1981; Nieves Aldrey, Vårdal and Ronquist, 2005), others focused on the formation of galls (Magnus, 1914; Shaeffer and Meyer, 1963; Redfern, 1997). Adler (1877), Callan (1940), Stille and Dävring (1980) dealt with reproduction and sexual behaviour, Bronner (1985) studied oviposition. Blair (1943, 1945, 1951), Randolph (2005) and others focused on D. rosae galls and biology. Vårdal, Sahlén and Ronquist (2003) studied the clutch size, size, shape and structure of eggs as well as the role of 
embryos in the process of gall formation. László and Tóthmérész (2008) examined the optimal clutch size, which differs from the most frequently recorded number of laid eggs (25-30). According to them, the most frequently recorded clutch size is suboptimal in relation to the proportion of successfully hatched progeny. Stille (1984) found out that total parasitisation and mortality of D. rosae decrease with the increasing gall size. László and Tóthmérész $(2007,2011)$ studied parasitisation of galls and its relation to the size of galls and spatial distribution of shrubs of Rosa spp. The authors demonstrated among other that the density of galls and their parasitation decrease with the increasing density of shrubs. Ferrari, Kruess and Tscharntke (1997) determined the influence of environment division and size of galls on their insect community.

Parasitoids of $D$. rosae and the inquiline species of Periclistus brandtii (Ratz.) (Cynipidae) were studied by Voukassovitch (1928), Judd (1959), Grigorov (1962), Nordlander (1973), Tudor and Caruntu (1980), Nieves Aldrey (1981), Doğanlar (1984), Bayram, Ülgentürk and Toros (1998), László (2001), Williams and Randolph (2002), László and Tóthmérész (2006, 2012, 2013a, b), Rizzo and Massa (2006), Hesami et al. (2008), Todorov et al. (2012), Liu, Zhang and Xiao (2012), Boyadzhiev and Todorov (2013), László, Rákosy and Tóthmérész (2014), Chireceanu et al. (2015), Mete and Mergen (2016) and others. Communities of various Hymenoptera species associated with the galls of little known D. mayri (Schl.) are mentioned by Askew, Sadeghi and Tavakoli (2006). Hintze-Podufal and Thiele (1998) compared the microfauna of grown-up and old galls after their hibernation. Blommers (2008) studied the occurrence of so-called successor insect species in the cavities of galls deserted by gall wasps D. rosae and their parasitoids and inquilines. Valuable are findings on the occurrence, hosts and biology of less known related species of D. japonica (Walk.) (Yasumatsu and Taketani, 1967). Rather sporadic are studies on galls pecked up by birds (Solyom, 2015).

Some authors, e.g. Stille and Dävring (1980), van Meer et al. (1995), or Plantard et al. (1999) mention the relation between parthenogenetic vermination (thelytokia) and infection by the bacteria from the family of Wolbachia (Hert.) (Rickettsiales) inducing the fusion of infecund female gametes. Kohnen, Wissemann and Brandl (2011) ascertained the common (up to 97\%) incidence of infected individuals in the population of D. rosae. Kohnen, Richter and Brandl (2012) studied the genetic diversity of $D$. rosae and its common parasitoids Orthopelma mediator (Thunb.) (Ichneumonidae) and Glyphomerus stigma (F.) (Torymidae). No genetic differences were detected among females from Rosa canina L., R. corymbifera and R. rubiginosa L. (Kohnen, Wissemann a Brandl, 2011). Czeczuga, Czeczuga-Semeniuk and Semeniuk (2008) studied qualitative and quantitative differences in the content of carotenoids in galls, leaves and fruits. These secondary substances may influence the choice of host plants. Only a few publications were focused on the possibilities of protection and defense against D. rosae in garden cultures and plantations of Rosa spp. (Lüstner, 1931; Gibson, 1935).

\section{MATERIALS AND METHODS}

Field surveys were conducted in the near surroundings of the city of Brno mainly in 2015 and 2016. Attention was paid to localities linked with the northern outskirts of Brno and managed by the Training Forest Enterprise Masaryk Forest Krrtiny, specifically to the forest districts of Bílovice nad Svitavou and Vranov. Most of the territory consists of the southernmost part of Drahanská vrchovina Upland natural forest region, and in the forest district of Bílovice nad Svitavou partly also the Protected Landscape Area of Moravian Karst. Numerous observations connected with the collection of galls took part in the forest region situated west of Brno, managed by Forest District Brno (Forests of Brno City/Lesy města Brna, a. s.). Occasional visits were made also to forest stands on the eastern margin of Brno belonging to the forest district of Pozořice (LČR, s. p./Forests of the Czech Republic, State Enterprise). The researched area stretches between $49^{\circ} 10^{\prime}-49^{\circ} 19^{\prime}$ of northern geographical latitude and $16^{\circ} 30^{\prime}-16^{\circ} 45^{\prime}$ of eastern geographical longitude. Ground surface orography is articulated with altitude above sea-level ranging from 230 to $400 \mathrm{~m}$. Average annual temperature is $7.5^{\circ} \mathrm{C}$, mean annual precipitation amounts to $610 \mathrm{~mm}$ and average growing season lasts 160 days.

The main goal of the study was to determine the hitherto little known course of the evolution of individual developmental stages (larvae in particular) of $D$. rosae on the wild growing $R$. canina in the Brno region. In 2015 and 2016, the galls were examined from June to December (March) at regular week intervals. Partial surveys were made also in 2014 and 2017. Each week, 1 to 5 galls were analyzed in the laboratory (Tabs. I and II). First, the diameter of shoots (right under the gall) and gall dimensions before (and after) the removal of stolons were measured. The galls were gradually cut by surgical knife under microscope. Dimensions of cells were measured micrometrically and the number of cells and their contents were recorded. The growth and development of D. rosae larvae and the species' inquiline Periclistus brandtii (Ratz.) was assessed according to the micrometrically measured cranium width and total body length and width. The complex examination of galls and their contents provided a basis for deducing the course of gall wasp development from oviposition up to emergence of imagos. The effect of mortality factors on cecidogenesis was among other things ascertained according to the average size of cells with the intact and impaired development of D. rosae. 


\section{RESULTS AND DISCUSSION}

\section{Incidence of imagos and vermination}

Diplolepis rosae hibernates in galls persisting on shrubs until the next year (possibly even longer). Unlike in most species from the Diplolepis spp. group, the galls remain on plants long after the emergence of imagos sometimes (Blommers, 2008). Thus, old (i.e. last year's and even older) galls and new (i.e. current year's) galls may occur simultaneously on the same shrubs. The species survives the winter period at the stage of grown-up larvae (Schröder, 1967) or prepupae (Williams, Shorthouse and Lee, 2003). According to Kieffer (1914), the galls maturate in the autumn and imagos hatch from them in the spring. In the Mediterranean region (Sicily), females hatch from March to June (Rizzo and Massa, 2006), in Sweden, as late as at the end of May and in early June (Stille and Dävring, 1980). Imagos of the related species D. japonica (Walk.) appear in Japan from April to the beginning of May within a period of three weeks (Yasumatsu and Taketani,
1967). Occurrence of adults in the spring and in early summer is regulated primarily by temperature, which ensures that gall wasp development is synchronized with the development of host plants (Schröder, 1967).

In the Brno region, D. rosae hibernates at the stage of grown-up larvae and prepupae. In winter $2015 / 2016$, its galls contained $30 \%$ of grown-up larvae (of which 20\% without pupal eyes and $10 \%$ with pupal eyes) and $70 \%$ of prepupae. In the winter period of $2016 / 2017$, the galls contained $53 \%$ of grown-up larvae (of which $28 \%$ without pupal eyes and $25 \%$ with pupal eyes) and $47 \%$ of prepupae. In 2016 and 2017, pupae occurred from 15 March to 15 July and from 20 March to 20 July, respectively. Imagos were hatching from April to July, i.e. four months (Tab. III). In the laboratory conditions, imagos from galls brought on 7 April 2015 were hatching from 5 April to 17 May (Fig. 1).

Males are rare in the population of $D$. rosae than females, and this is why the species verminates almost exclusively through parthenogenesis/parthenogenetically. Although

I: Basic data from field surveys: Average size of current year galls of D. rosae (including average number and size of cells in the galls)

\begin{tabular}{|c|c|c|c|c|c|c|c|c|}
\hline June & 8.15.22.29. & $3 / 3 / 1 / 3$ & 10 & 1.6 & $19.2 / 24.9$ & $11.1 / 15.1$ & 47.8 & $0.7 / 0.5$ \\
\hline July & 6.13.20.27. & $3 / 4 / 4 / 1$ & 9 & 1.8 & $24.8 / 30.8$ & $13.1 / 19.2$ & 67.7 & $2.0 / 1.5$ \\
\hline October & 5.12.19.26 & $3 / 1 / 3 / 3$ & 8 & 3.5 & $38.5 / 45.9$ & $19.8 / 28.6$ & 78.5 & $3.6 / 2.9$ \\
\hline November & 2.9.16.23.30 & $1 / 2 / 2 / 3 / 1$ & 10 & 3.8 & $36.1 / 45.2$ & $22.6 / 30.5$ & 51.9 & $3.7 / 3.0$ \\
\hline December & 7.14.21.28. & $1 / 1 / 1 / 4$ & 8 & 2.9 & $30.9 / 41.8$ & $18.9 / 29.9$ & 33.0 & $3.6 / 2.9$ \\
\hline $\begin{array}{l}\text { Total/ } \\
\text { Average }\end{array}$ & - & - & 63 & $(2.7)$ & $(30.1 / 38.4)$ & $(17.0 / 24.6)$ & 55.5 & $(2.8 / 2.2)$ \\
\hline
\end{tabular}

${ }^{*}$ Forest district Bílovice n. Sv., 2 - Forest district Vranov, 3 - Forest district Brno, 4 - Forest district Pozořice. Brno region, 8 June-28 December 2015

II: Basic data from field surveys: Average size of current year (up to one year old) galls of D. rosae (including average number and size of cells in the galls).

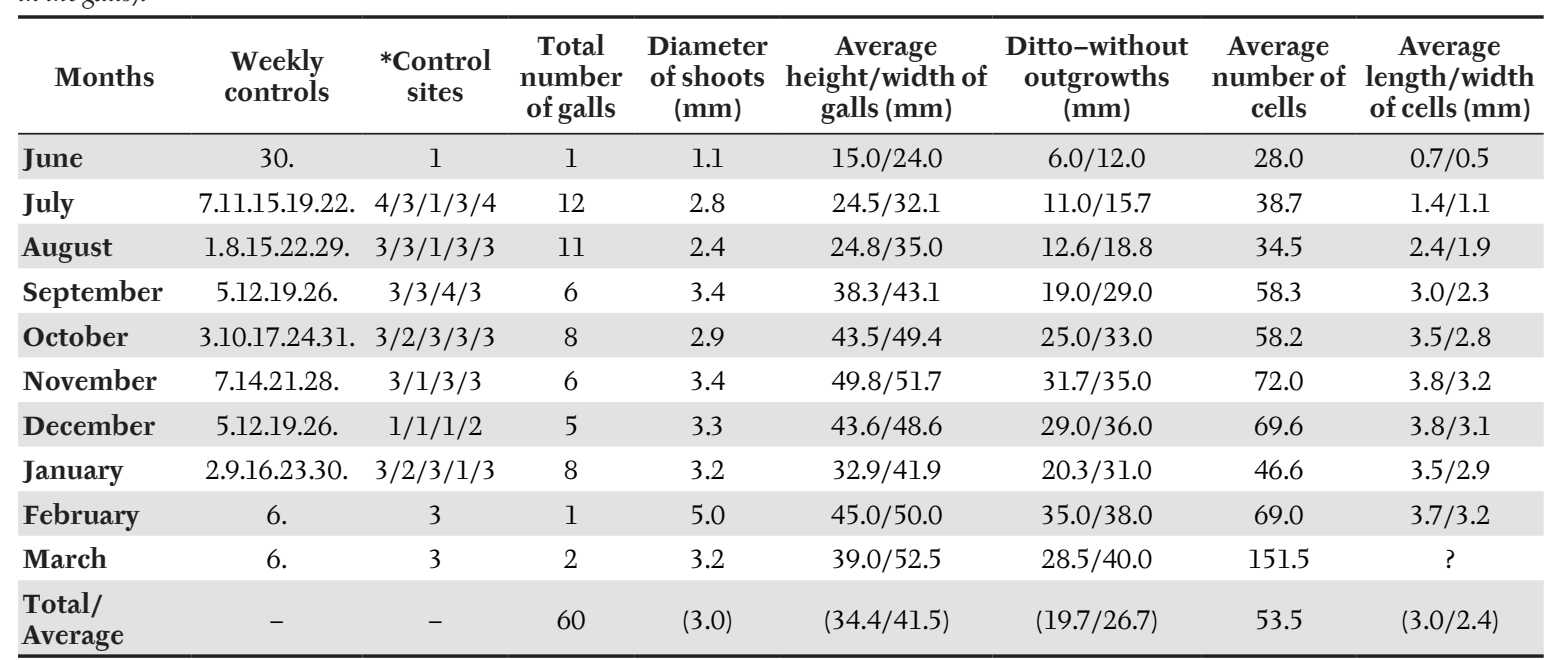

*Legend: see Tab. I, Brno region, 30 June 2016-6 March 2017 
the species is bisexual according to Gauss (1982), its extremely scarce males are of no importance for vermination. The specific type of parthenogenesis in which unfertilized females verminate by means of diploid eggs from which female progeny hatches again (i.e. thelytokia) is according to recent findings induced by infection caused by the symbiotic bacteria from the family of Wolbachia Hert. (Rickettsiales) (Shilthuizen and Stouthamer, 1998; Plantard et al., 1999). The authors found the bacteria in all studied populations of $D$. rosae as well as in a considerable proportion of examined individuals from a wider spectrum of European and non-arctic species of Diplolepis. This is why for example populations of D. spinosissimae (Gir.) with individuals without bacteria exhibited higher representation of males than populations with infected individuals. Apparently, the infection by Wolbachia plays an essential role in the vermination strategy of these gall wasps.

The very low (usually less than 1\%) representation of males (or their absence) in the populations of D. rosae is mentioned e.g. by Kieffer (1914), Schröder (1967) and Gauss (1982). Rizzo and Massa (2006) observed about $4.3 \%$ of males in Sicily and Askew (1960) found 0-4.2\% of males in England. The highest representation of the males of D. rosae in Europe (43.1\%) was reported from Bulgaria (Todorov et al., 2012). Populations of D. japonica (Walk.) in Japan had 3\% of males (Yasumatsu and Taketani, 1967).
In the Brno region, individuals of both sexes were hatching simultaneously and the share of males in the populations fluctuated from zero to $9 \%$ (on average ca. $4.5 \%)$.

Soon after their emergence from the galls, imagos search places suitable for oviposition-usually on shrubs on which they developed or on shrubs in the surroundings. Upon finding a properly breaking flower or leaf bud, they tuck the ovipositor among leaflets or flower parts and gradually lay eggs therein. Rarely, they lay eggs also into the shoots just below the buds. Following the oviposition and primarily due to the activity of freshly hatched larvae, galls start to develop on young leaves and/or on petals or sepals of flowers and on fruits.

Young, rapidly growing galls can be found in the open towards the end of May and in early June. Galls developing on leaves are at all times fixed to petiole or midrib, which become swollen due to the presence of eggs and larvae. Blades of effected leaves stop their further growth and become dwarfed. Individual leaflets and their residues often form a conspicuous base of some galls. The galls appear on the adaxial face of leaves first, later also on the abaxial face. In mid-June 2015, numerous galls on the shrubs of R. canina in Brno-Černá Pole grew from the adaxial face of 3-10 sepals on relatively well developed fruits (rose hips) of up to $14 \mathrm{~mm}$ in height and up to $11 \mathrm{~mm}$ in width. This indicates

III: Periods of individual developmental stages/instars of D. rosae. Arrow indicates hibernation of a part of the subpopulation of $2^{\text {nd }}$ instar larvae and prepupae. Brno region, 2015-2017

\begin{tabular}{lcc}
\hline \multicolumn{1}{c}{ Developmental stages/instars } & $\mathbf{2 0 1 5 / 2 0 1 6}$ (from-to) & $\mathbf{2 0 1 6 / 2 0 1 7}$ (from-to) \\
\hline Eggs & 25 May-25 July & 5 June-30 July \\
$\mathbf{1}^{\text {st }}$ instar larvae & 1 June-31 August & 10 June-5 September \\
$2^{\text {nd }}$ instar larvae & 1 July-20 May & 1 July-25 May \\
$2^{\text {nd }}$ instar larvae (pupal eyes) & 5 October-30 May & 5 October-30 May \\
Prepupae & 12 October-10 June & 10 October-15 June \\
Pupae & 15 March-15 July & 20 March-20 July \\
Imagos & 1 April-30 July & 10 April-25 July \\
\hline
\end{tabular}

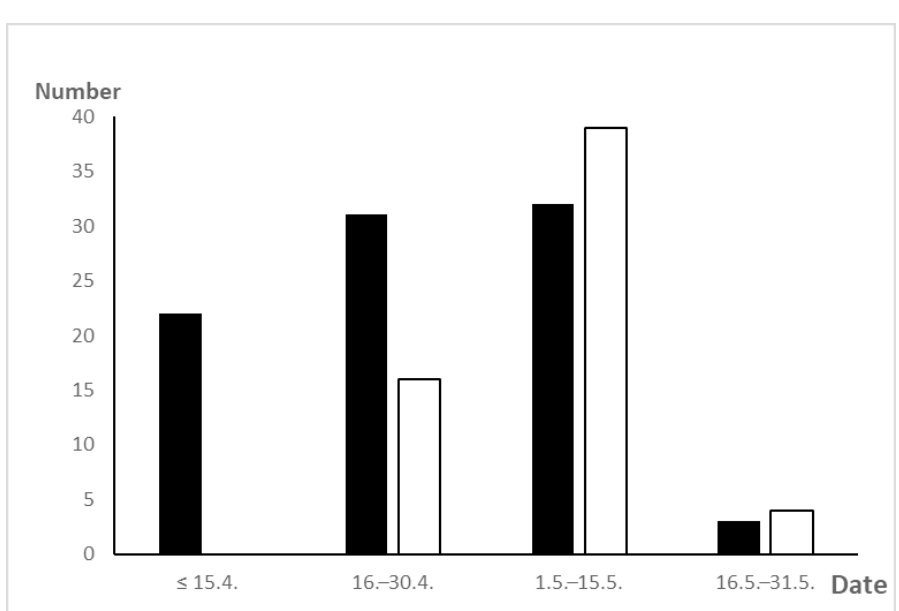

1: Emergence of imagos of Diplolepis rosae (dark) and Periclistus brandtii (light) from galls brought to laboratory on 7 April 2015 
that females laid eggs at up to 10 places from which individual galls were developing, which grew together into composite galls at the base, in whose centre (and/or at the base) fruits (rose hips) were situated. Partial galls could be separated from one another only with difficulties.

The galls of $D$. rosae usually consist of multiple cells. Being more or less grown together, their individual compact parts (with variable numbers of cells) optically represent a single gall. Detailed analyses revealed that females lay eggs at 1-20 (on average 7.0) places. Galls usually grow from one (max. from 4) buds occurring close to one another at a distance of up to $5 \mathrm{~mm}$. It was found out that the number of partial galls increases with the increasing gall size. Small galls (up to $20 \mathrm{~mm}$ ) usually consist of a single integral gall. These galls are induced by larvae hatched from eggs laid close to one another into a single, relatively tight space. Individual and common occurrence of galls close to one another is mentioned by Gusev and Rimskij-Korsakov (1953).

\section{The number of laid eggs}

Females of D. rosae can lay more than 700 eggs (Schröder, 1967). Vårdal, Sahlén and Ronquist (2003) found out that females produce on average 408 eggs. Stille and Dävring (1980) mention average fecundity of about 500 eggs, and according to them, females lay 5-10 eggs per hour in laboratory conditions. László and Tóthmérész (2008) observed that galls without parasitoids and inquilines contain most often 25-30 cells that are inhabited at all times only by a single larva. The variable number of eggs in the galls is documented also by Blair (1951) according to whom 50-100 imagos of D. rosae hatch from galls without parasitoids.

Galls of D. rosae in the Brno region exhibited 5-225 (av. 55.5) cells in 2015 and 1-165 (av. 53.5) cells in 2016 (Tabs. I and II). Thus, at an average number of 500 laid eggs, females could lay eggs on approximately nine different sites under optimal conditions. Nevertheless, the actual number of galls occurring in the open is far from corresponding to the reproduction capacity of females since a great part of laid eggs die and galls are not created. Responsible for the reduced population density of gall wasp are primarily parasitoids, defence reactions of host woody plants and unfavourable weather. Females live for a relatively short time during which they produce several partial clutches by which they induce formation of fewer galls.

Eggs of D. rosae are oblong (5 times longer than wide), with long peduncles. Their length is ca. $318 \mu \mathrm{m}$, width ca. $59 \mu \mathrm{m}$ and length of thin peduncle is ca. $917 \mu \mathrm{m}$ (Vårdal, Sahlén and Ronquist, 2003). They have a colourless, elastic chorion, which allows temporary move of a part of egg content into the peduncle during oviposition. Semipermeable egg membrane provides for chemical communication between the egg and the host plant tissue, through which the egg volume gradually grows.

\section{Creation of galls}

Plants respond to the growth of embryos in eggs and this is why the galls start to be created already at the time when the larvae are still in the eggs (Kieffer, 1914). Statements that are more recent claim that most participating in the creation of galls are freshly emerged egg larvae. The reason is that after hatching, irritants (secrets?) get into adjacent tissues and stimulate them to the fast proliferation (hypertrophy and hyperplasia) of procambial cells. The composition of these metabolites excreted especially by young larvae and showing apparently the nature of growth stimulators is not known yet. Apart from secrets excreted by the larvae, the proliferation of cells is to a lesser extent caused also by the mechanical wounding of cells by fine mouth organs of the larvae etc.

Internal structure of galls was studied e.g. by Shorthouse (1998) or Sliva and Shorthouse (2006). Cells of gall wasps are surrounded by concentrically arranged distinct layers of tissues. The internal layer is formed by nutritive cells, which represent the only source of feed for the larvae. During consumption, these cells are substituted by those from the outer (centrifugally located) intact layer of cells, which is joined to the vascular system of the plant. Characteristic for the histological structure of the galls of $D$. rosae is a continuous transition of the food cell layer into the parenchyma layer and absence of hard ("protective") cell layer, which is in the galls of many other gallfly species built of thick-walled lignified cells. Thus, the internal tissues of the galls of D. rosae are rather homogeneous from the trophic layer up to the epidermis. Young (current year's) galls always contain more water than the adjacent plant tissues.

The surface of the galls of $D$. rosae is covered with numerous moss-like branched outgrowths, which are sticky, soft and elastic at the time of gall growth while old outgrowths are non-sticky, hard and fragile. On the growing galls, they are pea-green, yellow-green and often red on ends (rarely whole). Rusty brown up to red are as a rule only distal (apical) parts of the outgrowths while their bases are green. The colour of galls however tells nothing about their age because even very young galls are often red and grown-up galls are frequently green. On dying and dead galls, the outgrowths turn rusty, brown and black. The shape of galls is globular, oval up to irregularly gnarled with a diameter ranging from 5 to $50 \mathrm{~mm}$ (Gusev and Rimskij-Korsakov, 1953; Miller, 1956). According to Nienhaus, Butin and Böhmer (1992), the galls are 4-5 cm large, according to Sedlag et al. (1986), their size is approximately as a baby fist, according to Kieffer (1914), Escherich (1942), Schimitschek (1944) and Kovalev (1981) about like a fist.

From the apically narrowing long and mildly warped outgrowths, numerous short (and often 
wavy) pointed branches shoot laterally. Outgrowths on the apical part and on the sides of galls are as a rule longer and branched while basal outgrowths are at all times shorter and often non-branched. A gall of average size (height $28 \mathrm{~mm}$ and width $37 \mathrm{~mm})$, localized on the apical part of rose hip sized $9 \mathrm{~mm}$ in both height and width) was only $15 \mathrm{~mm}$ high and $23 \mathrm{~mm}$ wide after the removal of outgrowths. There were 697 outgrowths on the gall, whose length ranged from 3 to $22 \mathrm{~mm}$ (av. $13.1 \mathrm{~mm}$ ). From this total number of outgrowths, 50 (7.3 \%) were shorter than $5 \mathrm{~mm}, 89$ (12.8 \%) were 5-10 mm long, 298 (42.7\%) were $10-15 \mathrm{~mm}$ long and 260 (37.3\%) were longer than $15 \mathrm{~mm}$. An above-average long outgrowth of $17 \mathrm{~mm}$ exhibited 55 lateral outgrowths that were $0.5-4.0 \mathrm{~mm}$ long and $0.1-0.25 \mathrm{~mm}$ wide (at the base). Outgrowths on the gall base were very short (up to $10 \mathrm{~mm}$ ) and wide $0.2-1.1 \mathrm{~mm}$ (av. $0.36 \mathrm{~mm}$ ) at the base. A very tiny leaf gall of $6 \mathrm{~mm}$ in both length and width featured only 50 small (usually non-branched) outgrowths.

The galls of D. rosae usually consist of several parts differing in size. Dense fimbriated outgrowths connect these partial segments, giving the galls a monolithic (compact) shape and mossy appearance. Even completely self-contained galls localized close to one another (on 2-4 neighbouring buds) are optically aggregated into a single voluminous gall by means of outgrowths. In Czech, the galls are commonly called as "růžová houba" (bedeguar). In Russian they are called "bedeguar", in German they are known as Rosenapfel, Rosenschwamm, Schlafapfel and "Bedeguar", in English as mossy rose gall, rose bedeguar gall (obsolete name is robin's pincushion) and in French "bédéguar". The striking appearance of the galls reflected also into the names in many other national languages.

In the Brno region, the galls of D. rosae appear earliest at the end of May and in early June; during June and July, they grow intensively. Their size increases during the growing period and the growth ends only as late as in October. In 2015, grown-up galls were on average $35.2 \mathrm{~mm}$ high $(20.6 \mathrm{~mm}$ without outgrowths) and $44.4(29.7) \mathrm{mm}$ wide. In the climatically more favourable year 2016, the galls were much larger-on average $45.5 \mathrm{~mm}$ (without outgrowths $28.2 \mathrm{~mm}$ ) high and 49.9 (34.4) $\mathrm{mm}$ wide (Tabs. I and II). The smallest galls with 1-2 cells were $10 \mathrm{~mm}$ (without outgrowths $4 \mathrm{~mm}$ ) high and $17 \mathrm{~mm}$ (without outgrowths $6 \mathrm{~mm}$ ) wide. The largest gall with 225 cells was $75 \mathrm{~mm}$ (without outgrowths $55 \mathrm{~mm}$ ) high and $85 \mathrm{~mm}$ (without outgrowths $70 \mathrm{~mm}$ ) wide. The average number of cells in the galls amounted to 52.3 and the highest number of galls (27.4\%) contained $21-40$ cells (Fig. 2).

Galls of D. rosae gain size even when the leaves are fully grown-up (Kieffer, 1914). Their final size depends on the continual feeding of larvae (Redfern, 1997). They persist on woody plants during winter and during the following year, sometimes even longer. Their tissues become darker and lignified. The general appearance of the galls and to a considerable extent also their size and shape alter due to age, climatic impacts and biotic factors. The originally fine pastel coloured "mossy" cover of the galls turns darker and even black; the fragile outgrowths flatten and often crumble down. The gall "body" becomes partly exposed and often features visible craters made by birds, rarely by small rodents.

\section{Localization and size differentiation of galls}

Galls of D. rosae are created only on young and vital annual shoots of Rosa spp. In the Brno region, a majority of galls (63.5\%) was localized on shoot sides (of which $35.3 \%$ on a smaller or larger part of shoot girth and $28.2 \%$ everywhere around the shoot). Smaller galls were situated on the shoots usually on one side while large galls (consisting of several more or less elements) encircled the shoot all around. More than a third of galls (36.5\%) occurred on the apical growing point or in its close vicinity. While pleurocecidia usually only suppress the growth of shoots, acrocecidia usually terminate their length growth.

As a rule (85.1\%), the gall wasp infested breaking or freshly broken leaves. Far fewer galls (14.9\%) were found on flowers and fruits (rose hips). A possibility of the formation of galls from multiple buds can be documented by rather abundant findings of

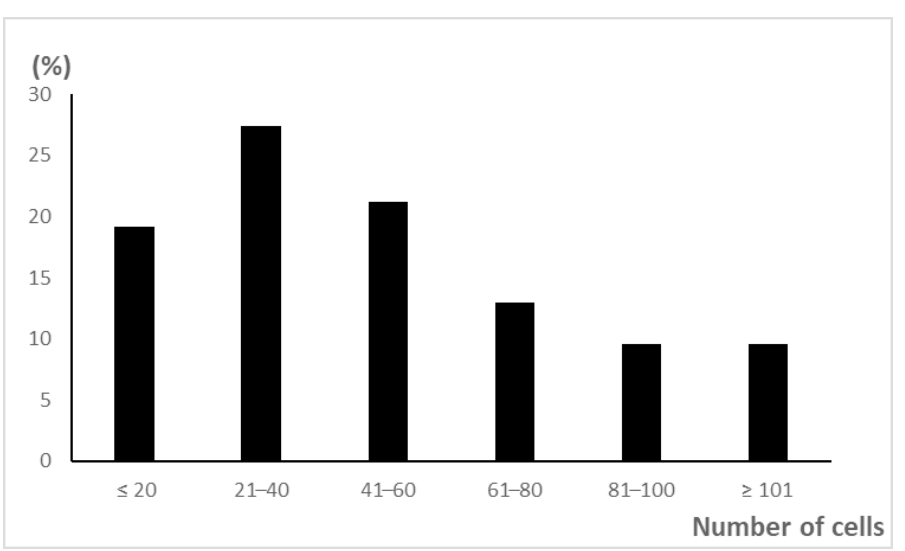

2: Number of cells in the galls of D. rosae (in \% from the total number of galls). Brno region, June-December 2015, 2016 


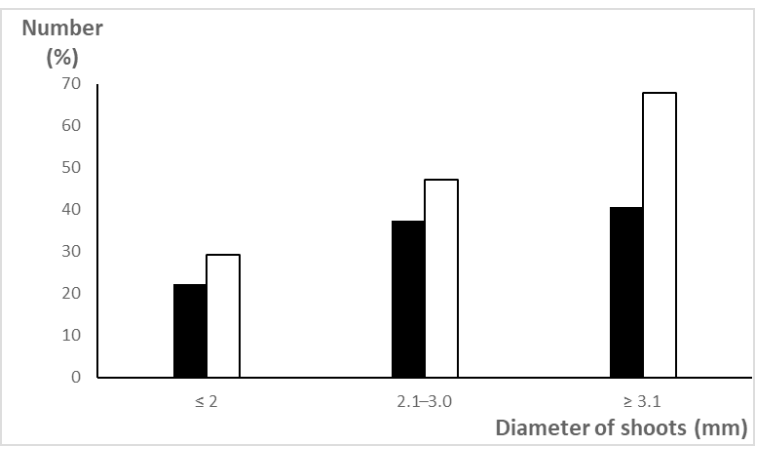

3: Relation between the diameter of grown-up annual shoots of Rosa canina and the relative numerical representation of galls of D. rosae (dark); Relation between the diameter of shoots and the number of cells in the galls (light); Brno region, 2015, 2016

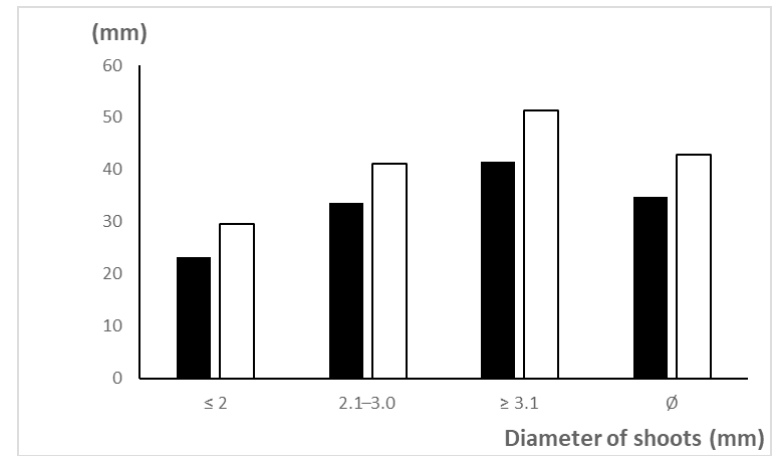

4: Relation between the diameter of grown-up annual shoots and the average gall height (dark) and width (light); Brno region, September-December 2015, 2016

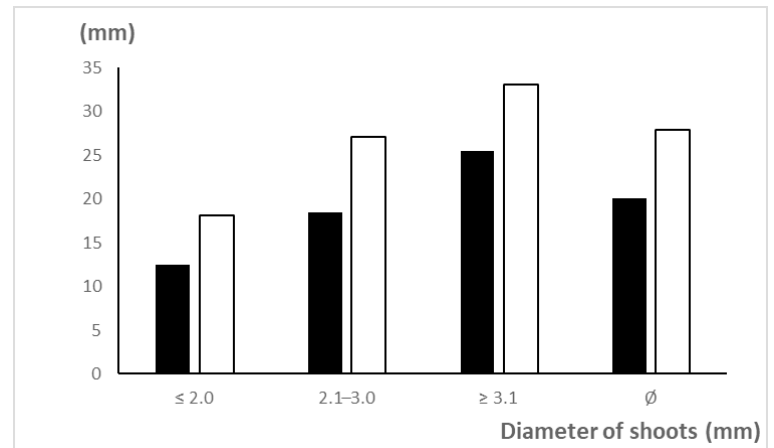

5: Relation between the diameter of grown-up annual shoots and the average gall height (dark) and width (light) after removal of the outgrowths; Brno region, September-December 2015, 2016

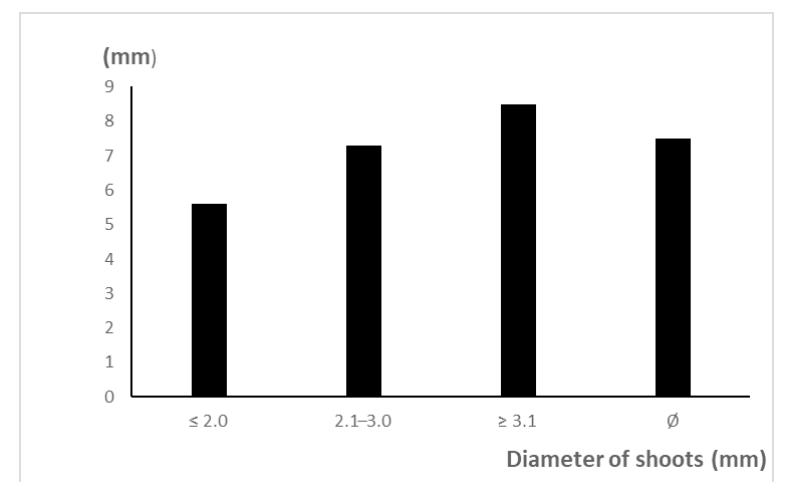

6: Dependence of the average length of outgrowths on the diameter of grown-up annual shoots; Brno region, September - December 2015, 2016 
galls with 1-3 normally developed fruits that were partly or completely hidden in the galls. Rarely, galls were created directly on the shoots, at all times in the immediate vicinity of bud bases.

Females of D. rosae are highly selective in choosing plants suitable for oviposition. This is among other things documented by the repeated infestation of the same shrubs and a great variability in the number of laid eggs in individual clutches. The number of eggs in the clutch is doubtlessly affected by the vitality of woody plants and related growth rate, by the size and stage of bud flushing, localization of buds on the shrubs etc. The species settles down primarily on the wild $R$. canina, to a lesser extent on other wild growing rose species or rose species escaped from cultivation and rarely on cultivated rose species. Galls can be commonly found on shrubs in forest steppes, in open broadleaved woods, on forest rides and margins, balks, along communications and on various bushy sites. According to Schröder (1967), the galls are more abundant on exposed sites with the annual precipitation below $762 \mathrm{~mm}$ and temperature reaching up to $60-80^{\circ} \mathrm{F}\left(15.6-26.7^{\circ} \mathrm{C}\right)$.

The size of D. rosae galls (without inquilines) is in a positive correlation with the number of cells (László and Tóthmérész, 2013b). The relation between the gall size and the number of emerged gall wasps is impaired by inquilines, which also have some importance in shaping the structure of gall communities (László and Tóthmérész, 2006). However, the differentiation of gall size does not depend on parasitisation and mortality of gall-forming insects (László and Tóthmérész, 2008). With the increasing size of galls, the percentage of parasitisation decreases and the proportion of emerged progeny is increasing (Ferrari et al., 1997; László and Tóthmérész, 2008). The survival of D. rosae increases with the increasing size of galls and decreases with the increasing distance of galls from the ground (László, 2001). The abundance of galls decreases also with the increasing density of shrubs (László and Tóthmérész, 2011). It is stated that the gall wasp infests primarily shrubs stressed by drought, deficiency of nutrients, pruning and the like. It is however not known whether the vitality of shrubs impairs oviposition or whether it suppresses creation of galls. According to the prevailing opinion, young and stressed woody plants tend to produce larger and more abundant galls than old and intact woody plants.

Detailed surveys conducted in the Brno region in 2015-2017 revealed that both the absolute

IV: Head (cranium) width and length $/$ width of vital $1^{\text {st }}$ and $2^{\text {nd }}$ instar larvae of D. rosae ( 1 division $=0.0357 \mathrm{~mm}$ ). Average cranium width of

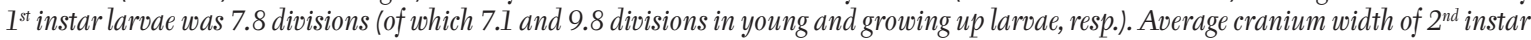
larvae was 15.3 divisions (of which 15.1 and 15.4 divisions in young and growing up larvae, resp.). Brno region, 8 June-28 December 2015 and 30 June-6 February 2017

\begin{tabular}{|c|c|c|c|c|c|c|c|c|c|}
\hline \multirow{2}{*}{$\begin{array}{l}\text { Cranium } \\
\text { width (div.) }\end{array}$} & \multicolumn{3}{|c|}{ Living larvae } & \multicolumn{3}{|c|}{ Average length of larvae (div.) } & \multicolumn{3}{|c|}{ Average width of larvae (div.) } \\
\hline & Total & Young & $\begin{array}{l}\text { Growing } \\
\text { up }\end{array}$ & Total & Young & $\begin{array}{l}\text { Growing } \\
\text { up }\end{array}$ & Total & Young & $\begin{array}{c}\text { Growing } \\
\text { up }\end{array}$ \\
\hline 4 & 8 & 5 & - & 16.2 & 18.0 & - & 5.8 & 5.6 & - \\
\hline 5 & 19 & 10 & - & 14.1 & 13.1 & - & 6.8 & 7.0 & - \\
\hline 6 & 61 & 27 & 1 & 14.1 & 13.9 & 30.0 & 7.9 & 7.7 & 13.0 \\
\hline 7 & 50 & 12 & 3 & 15.7 & 15.3 & 32.3 & 9.2 & 8.5 & 14.0 \\
\hline 8 & 42 & 20 & 7 & 16.5 & 15.9 & 19.4 & 10.3 & 10.2 & 10.9 \\
\hline 9 & 33 & 7 & 9 & 19.3 & 18.0 & 20.9 & 11.5 & 10.3 & 12.9 \\
\hline 10 & 35 & 5 & 26 & 24.1 & 19.4 & 26.5 & 13.5 & 11.4 & 15.4 \\
\hline 11 & 26 & 5 & 14 & 25.0 & 22.2 & 24.1 & 13.9 & 13.2 & 13.6 \\
\hline 12 & 3 & 1 & 4 & 26.7 & 32.0 & 30.5 & 14.6 & 16.0 & 16.3 \\
\hline $\begin{array}{c}\text { Total/ } \\
\text { Average }\end{array}$ & 277 & 92 & 64 & 17.9 & 15.9 & 25.0 & 10.1 & 9.0 & 14.1 \\
\hline Average (mm) & - & - & - & 0.64 & 0.57 & 0.89 & 0.36 & 0.32 & 0.50 \\
\hline 12 & 14 & 3 & 5 & 49.2 & 32.3 & 76.4 & 24.4 & 16.0 & 31.8 \\
\hline 13 & 69 & 18 & 18 & 59.1 & 45.7 & 77.5 & 27.0 & 21.0 & 35.0 \\
\hline 14 & 168 & 44 & 55 & 68.0 & 46.7 & 94.7 & 29.5 & 21.9 & 39.3 \\
\hline 15 & 429 & 65 & 210 & 87.0 & 56.9 & 104.4 & 36.2 & 25.0 & 42.1 \\
\hline 16 & 388 & 45 & 185 & 97.8 & 65.2 & 112.0 & 39.1 & 28.3 & 43.5 \\
\hline 17 & 143 & 21 & 51 & 87.2 & 63.2 & 105.0 & 38.1 & 29.3 & 42.1 \\
\hline 18 & 33 & 4 & 7 & 86.1 & 65.0 & 105.7 & 38.1 & 35.7 & 38.6 \\
\hline 19 & 2 & 1 & - & 90.0 & 40.0 & - & 42.5 & 25.0 & - \\
\hline Total/Average & 1246 & 201 & 531 & 85.8 & 55.9 & 104.9 & 35.8 & 25.2 & 41.9 \\
\hline Average (mm) & - & - & - & 3.06 & 2.00 & 3.74 & 1.28 & 0.90 & 1.50 \\
\hline
\end{tabular}


and the relative representation of galls increases with the increasing diameter of grown-up annual year shoots (measured right below the galls) and the average number of cells in the galls demonstrably increases, too (Fig. 3). Demonstrably increasing with the growing diameter of grown-up annual shoots is also the average size (i.e. height and width) of galls with outgrowths as well as after their removal (Figs. 4, 5) and the average length of outgrowths increases too (Fig. 6). The research showed that the galls of D. rosae in the Brno region were most abundant and largest on vital shoots with a high annual increment.

\section{Preimaginal development}

Embryonal development of $D$. rosae begins right after oviposition and larvae start hatching from the eggs within a few days. Regarding the long period of oviposition, eggs were found in the Brno region from the end of May or early June up to the end of July, i.e. during the period of two months. Egg larvae emerged within 7-10 days after oviposition. In 2015, larvae of the $1^{\text {st }}$ instar occurred in the period from June to August; in 2016, it was by about a week later (Tab. III). At the beginning of July, larvae of the $2^{\text {nd }}$ instar started to occur in the enlarging cells, which were developing during a greater part of the growing season and came to age in September and October. A part of the grown-up larvae $(70 \%$ and $47 \%$ in 2015 and 2016, resp.) moulted as early as at the end of the growing season and wintered at a stage of prepupa. Larvae emerged from eggs that were laid later came to age too but survived winter in the $2^{\text {nd }}$ instar. The percentage of larvae hibernating in the winter of $2015 / 2016$ and $2026 / 2017$ was $30 \%$ and $53 \%$, respectively. The development of D. rosae in the galls was apparently accelerated in 2015 by the extremely warm and dry growing season.

Data about the number and development of individual instars of larvae were obtained from the micrometrical measurement of the width of their cranium shell and body (length and width) size (Tab. IV). The table shows among other things that the cranium of the $1^{\text {st }}$ instar larvae is $4-12$ divisions (0.14-0.43 mm) wide, and since it is only weakly sclerotised, it can gradually become larger during the growth. The average width of cranium in the $1^{\text {st }}$ instar larvae was 7.8 divisions $(0.28 \mathrm{~mm})$; however, the average cranium width of young larvae of this instar was only 7.1 divisions $(0.25 \mathrm{~mm})$ and the average cranium width of growing up and grown-up larvae was 9.8 divisions $(0.35 \mathrm{~mm})$. This indicates that the cranium width of the $1^{\text {st }}$ instar larvae became larger by 38\% during their growth. The larvae of this instar are on average $0.64 \mathrm{~mm}$ long and $0.36 \mathrm{~mm}$ wide and their body proportions gradually grow in the course of feeding. The increase of average cranium width and body length and width in the $1^{\text {st }}$ instar larvae is apparent from Tab. V.

In the climatically extremely dry and warm growing season of 2015 , the $1^{\text {st }}$ instar larvae were on average smaller (except for cranium) than those in the climatically more favourable year 2016. In 2015, the larvae were on average $0.58 \mathrm{~mm}$ long; in 2016, their length was $0.70 \mathrm{~mm}$ (i.e. by $20.2 \%$ greater). The average width of their cranium in 2015 was $0.30 \mathrm{~mm}$ while in 2016 it was $0.26 \mathrm{~mm}$ (i.e. by $8.6 \%$ narrower). The extremely unfavourable weather of 2015 reflected in the average cranium width increased by $6.9-22.2 \%$ (av. $8.6 \%$ ) and in the average body length decreased by $20.2 \%$. The average width of the body was practically not affected by the extreme weather. The same trends were demonstrated also in the size of young, growing up and grown-up $1^{\text {st }}$ instar larvae.

As opposed to the $1^{\text {st }}$ instar larvae, the cranium of the $2^{\text {nd }}$ instar larvae is more sclerotized and its width hardly increases during the growth (Tab. VI). Cranium width was from 12 to 19 (av. 15.3) divisions, i.e. 0.50-0.68 (av. 0.55) mm (Tab. IV). Average cranium width during feeding increased from 15.1 to 15.4 divisions, i.e. from 0.54 to $0.55 \mathrm{~mm}$ (by $1.9 \%$ ). After moulting, the larvae consume their exuvia, and this is why it was formerly believed they do not moult at all. According to sporadic unverified data, the larvae have allegedly $3-5$ instars.

The different weather in 2015 and 2016 had practically no significant influence on the average cranium width. Nevertheless, it had a great impact on the size of larvae. In the extremely warm and dry growing season of 2015 , the larvae were on average $2.8 \mathrm{~mm}$ long while in the climatically more favourably year 2016, their length was $3.3 \mathrm{~mm}$ (i.e. by $15.6 \%$ greater). In 2015 , the larvae were on average $1.20 \mathrm{~mm}$ wide while their width in 2016 was $1.36 \mathrm{~mm}$ (i.e. by $13.7 \%$ greater). In 2015 , the grown-up larvae were on average $3.5 \mathrm{~mm}$ long while their length in 2016 was $4.0 \mathrm{~mm}$ (i.e. by $14.7 \%$ greater). In 2015, the grown-up larvae were $1.38 \mathrm{~mm}$ wide while in 2016 their width was $1.62 \mathrm{~mm}$ (i.e. by $17.3 \%$ greater). Tropical heats and critical drought in the period from 20 June to 31 July 2015 reflected in the growth of larvae which (with the same width of cranium) reached markedly smaller average sizes at the end of the feeding period than in the climatically more favourable year 2016 (Tab. VI).

Cranium width of $D$. rosae and inquiline species Periclistus brandtii is illustrated in Fig. 7. The length and width of the larvae of both gall wasp species increase with the increasing cranium width (Figs. 8 and 9). The grown-up larvae of D. rosae are yellowy unlike the eating larvae, which are whitish. Their body is slightly dorsoventrally flattened, very distinctly segmented, widest at a half of body length or beyond. The end of their body is distinctly elongated (almost like a tail).

The larvae of D. rosae ingest from June to October. Regarding the long period of emergence of imagos and oviposition, the actual time of feeding is considerably shorter (ca. 3 months). The first larvae come of age in the $2^{\text {nd }}$ half of August; the last ones come of age in the $2^{\text {nd }}$ half of September and at the beginning of October. The grown-up larvae stop 


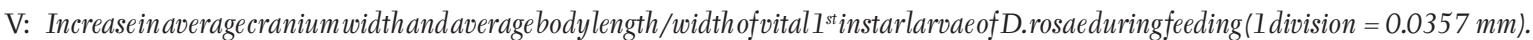
Brno region, 2015, 2016

\begin{tabular}{lcccc}
\hline \multirow{2}{*}{ Month } & \multicolumn{2}{c}{ Number of larvae } & \multicolumn{2}{c}{$\begin{array}{c}\text { Average cranium width/body } \\
\text { length/body width }\end{array}$} \\
\cline { 2 - 5 } & $\mathbf{2 0 1 5}$ & $\mathbf{2 0 1 6}$ & $\mathbf{2 0 1 5}$ & $\mathbf{2 0 1 6}$ \\
\hline June & 115 & 15 & $7.6 / 14.4 / 9.1$ & $6.3 / 15.4 / 8.7$ \\
July & 12 & 98 & $9.8 / 25.4 / 15.1$ & $7.2 / 19.5 / 10.1$ \\
August & 21 & 10 & $10.2 / 19.3 / 12.4$ & $10.0 / 23.6 / 12.4$ \\
Total/Average (divisions) & 148 & 123 & $8.1 / 16.0 / 10.1$ & $7.3 / 19.3 / 10.1$ \\
(mm) & - & - & $0.29 / 0.57 / 0.36$ & $0.26 / 0.69 / 0.36$ \\
\hline
\end{tabular}

VI: Average cranium width and average body length/width of vital $2^{\text {nd }}$ instar larvae of D. rosae (without pupal eyes) during feeding (1 division $=0.0357 \mathrm{~mm}$ ). Numbers of larvae examined in 2015 and 2016 were 709 and 566, resp. In the climatically extreme year 2015, the larvae were considerably smaller (with the exception of cranium). Brno region

\begin{tabular}{lccc}
\hline \multirow{2}{*}{ Month } & \multicolumn{2}{c}{ Average cranium width/body length/body width } \\
\cline { 2 - 4 } & $\mathbf{2 0 1 5}$ & $\mathbf{2 0 1 6}$ & average \\
\hline July & $15.7 / 66.8 / 30.1$ & $15.6 / 70.8 / 30.6$ & $15.7 / 68.3 / 30.3$ \\
August & $15.2 / 73.2 / 31.5$ & $15.0 / 78.2 / 31.0$ & $15.1 / 75.5 / 31.3$ \\
September & $15.2 / 92.0 / 38.2$ & $15.6 / 107.9 / 43.2$ & $15.4 / 99.5 / 40.6$ \\
October & $15.1 / 88.7 / 37.7$ & $15.3 / 117.8 / 46.0$ & $15.2 / 104.2 / 42.1$ \\
November & $14.5 / 84.1 / 33.8$ & $16.4 / 115.0 / 45.4$ & $14.8 / 88.9 / 35.6$ \\
December & $16.2 / 118.8 / 39.5$ & $15.7 / 97.4 / 45.2$ & $16.0 / 108.8 / 42.2$ \\
Average (divisions) & $15.3 / 81.9 / 34.2$ & $15.4 / 93.1 / 38.0$ & $15.4 / 87.1 / 35.9$ \\
(mm) & $0.55 / 2.92 / 1.22$ & $0.55 / 3.32 / 1.36$ & $0.55 / 3.11 / 1.28$ \\
\hline
\end{tabular}

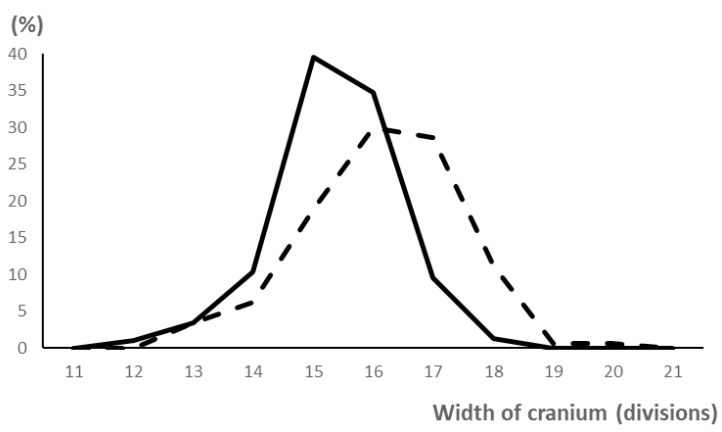

7: Cranium width in the grown-up larvae of D. rosae (full line) and P. brandtii (hatched line). Cranium of D. rosae was wide on average 15.4 divisions; cranium of P. brandtii was wide on average 16.1 divisions (1 division $=0.0357 \mathrm{~mm}$ ). Brno region, 2015-2017

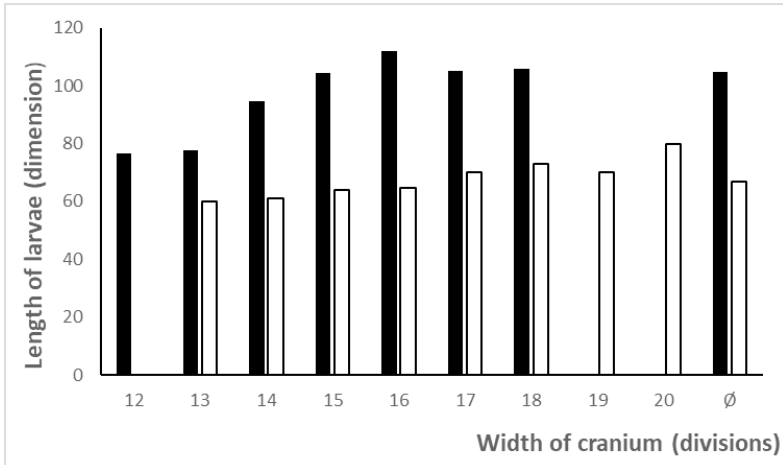

8: Length of the grown-up larvae of D. rosae (dark) and P. brandtii (light) in dependence on cranium width (1 division $=0.0357 \mathrm{~mm}$ ). Brno region, 2015-2017 


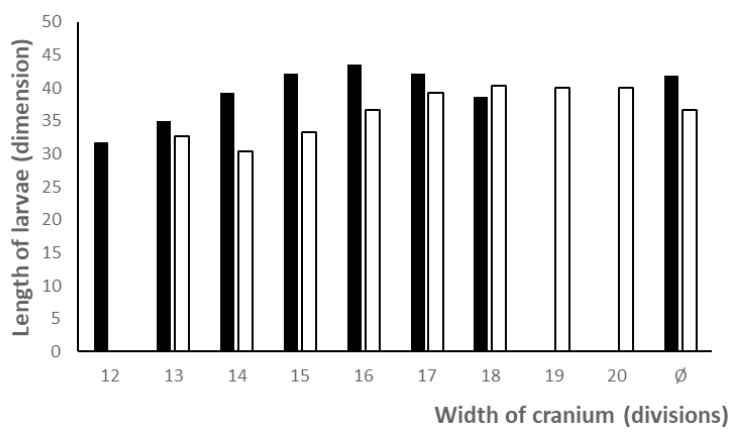

9: Width of the grown-up larvae of D. rosae (dark) and P. brandtii (light) in dependence on cranium width (1 division $=0.0357 \mathrm{~mm}$ ). Brno region, 2015-2017

VII: Cranium width of $2^{\text {nd }}$ instar larvae with interlucent compound eyes and their length and width (in dependence on cranium width) (1 division $=0.0357 \mathrm{~mm}$ ). Average cranium width in 2015 and 2016 was 15.4 divisions $(0.55 \mathrm{~mm})$ and 15.6 divisions $(0.56 \mathrm{~mm})$, resp. The last two columns show average cranium width of developing prepupae. Brno region, 12 October - 28 December 2015 and 10 October-26 December 2016

\begin{tabular}{ccccccccc}
\hline \multirow{2}{*}{ Cranium width } & \multicolumn{2}{c}{ Number of larvae } & \multicolumn{2}{c}{ Average body length } & \multicolumn{2}{c}{ Average body width } & \multicolumn{2}{c}{$\begin{array}{c}\text { Average cranium width } \\
\text { of prepupae }\end{array}$} \\
\cline { 2 - 10 } & $\mathbf{2 0 1 5 / 1 6}$ & total & $\mathbf{2 0 1 5 / 1 6}$ & total & $\mathbf{2 0 1 5 / 1 6}$ & total & $\mathbf{2 0 1 5 / 1 6}$ & total \\
\hline 13 & $1 / 1$ & 2 & $125.0 / 130.0$ & 127.5 & $40.0 / 45.0$ & 42.5 & $28.0 / 25.0$ & 26.5 \\
\hline 14 & $10 / 5$ & 15 & $134.5 / 130.0$ & 133.0 & $47.2 / 51.8$ & 48.7 & $31.1 / 27.6$ & 29.9 \\
15 & $73 / 41$ & 114 & $135.3 / 138.8$ & 136.6 & $46.9 / 50.4$ & 48.2 & $31.0 / 29.6$ & 30.5 \\
\hline 16 & $46 / 46$ & 92 & $138.3 / 134.5$ & 136.4 & $47.1 / 50.2$ & 48.6 & $31.4 / 29.9$ & 30.7 \\
17 & $7 / 9$ & 16 & $130.0 / 128.9$ & 129.4 & $43.3 / 50.0$ & 47.1 & $28.9 / 30.6$ & 29.8 \\
\hline 18 & $4 / 1$ & 5 & $118.8 / 100.0$ & 115.0 & $38.8 / 50.0$ & 41.0 & $29.0 / 36.0$ & 30.4 \\
19 & $1 /-$ & 1 & $110.0 /-$ & 110.0 & $37.0 /-$ & 37.0 & $27.0 /-$ & 27.0 \\
\hline Total/ Average & $142 / 103$ & 245 & $135.2 / 135.1$ & 135.2 & $46.5 / 50.3$ & 48.1 & $30.9 / 29.7$ & 30.4 \\
\hline (mm) & - & - & $4.83 / 4.82$ & 4.83 & $1.66 / 1.80$ & 1.72 & $1.10 / 1.06$ & 1.08 \\
\hline
\end{tabular}

VIII: Cranium width, body length/width of D. rosae prepupae (1 division $=0.0357 \mathrm{~mm}$ ). In 2015 and 2016, average cranium width was 27.2 divisions $(0.97 \mathrm{~mm})$ and 27.7 divisions $(0.99 \mathrm{~mm})$, resp. Brno region, 12 October-28 December 2015 and 10 October 2016-6 February 2017

\begin{tabular}{ccccccc}
\hline \multirow{2}{*}{ Cranium width } & \multicolumn{2}{c}{ Number } & \multicolumn{2}{c}{ Average length } & \multicolumn{2}{c}{ Average width } \\
\cline { 2 - 7 } & $\mathbf{2 0 1 5 / 1 6}$ & total & $\mathbf{2 0 1 5 / 1 6}$ & average & $\mathbf{2 0 1 5 / 1 6}$ & average \\
\hline 20 & $1 / 1$ & 2 & $100.0 / 80.0$ & 90.0 & $33.0 / 25.0$ & 29.0 \\
21 & $1 /-$ & 1 & $100.0 /-$ & 100.0 & $33.0 /-$ & 33.0 \\
22 & $5 / 4$ & 9 & $105.0 / 97.5$ & 101.7 & $34.2 / 33.0$ & 33.7 \\
23 & $7 / 8$ & 15 & $105.7 / 106.3$ & 106.0 & $35.6 / 33.9$ & 34.7 \\
25 & $6 / 11$ & 17 & $105.8 / 102.3$ & 103.5 & $35.8 / 34.7$ & 35.1 \\
26 & $22 / 23$ & 45 & $110.7 / 107.4$ & 109.0 & $35.7 / 36.3$ & 36.0 \\
27 & $24 / 41$ & 65 & $112.7 / 115.2$ & 114.3 & $37.4 / 36.8$ & 37.0 \\
28 & $36 / 51$ & 87 & $118.2 / 120.4$ & 119.5 & $38.1 / 38.3$ & 38.2 \\
29 & $36 / 67$ & 103 & $120.1 / 122.4$ & 121.6 & $39.4 / 38.7$ & 38.9 \\
30 & $24 / 62$ & 86 & $121.3 / 126.0$ & 124.7 & $39.5 / 39.8$ & 39.7 \\
31 & $23 / 48$ & 71 & $126.7 / 127.2$ & 127.0 & $40.9 / 40.6$ & 40.7 \\
32 & $3 / 8$ & 11 & $130.0 / 128.8$ & 129.1 & $42.3 / 40.3$ & 40.8 \\
\hline 33 & $2 / 5$ & 7 & $125.0 / 127.2$ & 126.6 & $42.5 / 40.0$ & 40.7 \\
34 & $2 /-$ & 2 & $130.0 /-$ & 130.0 & $47.5 /-$ & 47.5 \\
\hline 35 & - & - & - & - & - & - \\
\hline Total & $-/ 1$ & 1 & $-/ 120.0$ & 120.0 & $-/ 40.0$ & 40.0 \\
\hline (mm) & $192 / 330$ & 522 & $117.4 / 120.3$ & 119.2 & $38.2 / 38.4$ & 38.3 \\
\hline
\end{tabular}


eating and their body slightly shortens. On the inner light-brown to brown wall of cells, there is matt brown meconium which later turns black. During the period of ingestion, liquid dejecta accumulate in the digestive tract, which after their single excretion stick to $20-30 \%$ of the inner surface of cells.

Larvae hatched from eggs laid earlier started developing pupal eyes on the sides of cranium from 5 October, and the larvae moulted a week later. Average length and width of the $2^{\text {nd }}$ instar larvae with interlucent compound eyes is presented in Tab. VII. Prepupae and grown-up larvae hibernated and further developed only towards the end of winter and at the beginning of the next year. The prepupae exhibited the average cranium width of $0.98 \mathrm{~mm}$, length of $4.26 \mathrm{~mm}$ and width of $1.37 \mathrm{~mm}$ (Tab. VIII). As compared with the $2^{\text {nd }}$ instar larvae, they were immobile, their mouth organs were less distinct as well as their body segmentation, the end of their body was not tapered and their colour was achromatic up to lightly yellow-grey.

Pupae of D. rosae appear in the Brno region from mid-March to mid-July. Similarly as in the other cecidogeneous Cynipidae species, the pupal stage lasts only a few days. The pupae have a head wide on average $1.18 \mathrm{~mm}$; their body length and width is on average $4.0 \mathrm{~mm}$ and $1.47 \mathrm{~mm}$, resp. Imagos hatch from the beginning of April (possibly from mid-April) to the end of July (Tab. III). Their cranium width is on average $1.12 \mathrm{~mm}$, and their body length and width is $3.80 \mathrm{~mm}$ and $1.1 \mathrm{~mm}$, resp. (Tab. IX). An overall review of the average size of individual developmental stages (incl. instars) is presented in Tab. X.

\section{The size of cells}

From the oviposition to the occurrence of prepupae, the average size (length and width) of cells with intact development of $D$. rosae increases (Tab. XI). After the end of ingestion, the cells are on average $3.9 \mathrm{~mm}$ long and $3.1 \mathrm{~mm}$ wide. However, grown-up larvae of the $2^{\text {nd }}$ instar with interlucent pupal eyes are on average $4.83 \mathrm{~mm}$ long. In order to fit into the cells, their bodies are ventrally bent halfway through. In 2016 (more favourable for the growth of larvae), the cells were on average larger than in the extremely warm and dry year 2015. In addition to the smaller body size, the unfavourable weather in the growing season of 2015 reflected also in the smaller dimensions of cells.

The largest cells are in galls with the grown-up larvae (Tab. XII). The thickness of cells walls ranges from 0.1 to $0.9 \mathrm{~mm}$ (at gall circumference up to $5 \mathrm{~mm}$ ). In October (i.e. after the end of ingestion), the galls gradually start to turn brown and hard (lignified). Following the lump excretion of dejecta, some larvae moult and then become slightly shorter. Then inconspicuous whitish exuvia appear in the galls apart from the prepupae. On the other hand, the inner walls of cells with the larvae of parasitoids are usually light grey up to lightly grey-pink with the darker to black residues of killed larvae of hosting gall wasps.

Cells with the impaired development of D. rosae and cells of inquiline Periclistus brandtii are usually smaller than those with the intact gall wasp development are. Cells with parasitoids were on average by $15.3 \%$ shorter and by $16.0 \%$ narrower. Cells with the larvae dead due to physiological reasons (namely extreme drought) were on average by $24.3 \%$ shorter and by $24.6 \%$ narrower. The smallest were the cells of P. brandtii, which were on average by $43.6 \%$ shorter and $50.6 \%$ narrower as compared with the cells of D. rosae with the intact development (Tabs. XII and XIII).

\section{Inquiline Periclistus brandtii (Ratz.)}

Galls of D. rosae often become the place of developing inquiline $P$. brandtii (Cynipidae). As the other inquilines associated with galls of the genus of Diplolepis spp., this species is classified with the rather abundant monophyletic Synergini tribe (Ronquist, 1999), too. Females lay eggs into developing galls. Hatched larvae live mostly together in the self-contained thin-walled cells in the peripheral gall tissues. They cause proliferation of gall parenchyma to create cells of their own and to differentiate their own nutritive cells (Shorthouse, 1998). In literature, P. brandtii is usually taken for a harmless inhabitant of galls. According to Wiebes-Rijks and Shorthouse (1992) and László and Tóthmérész (2006), inquilines enlarge the galls, thus disturbing the positive correlation between the number of galls and the number of D. rosae individuals. Galls occupied by inquilines represent a food source for parasitoids, by which they participate in increasing the diversity of communities in the galls of D. rosae. According to Blair (1943), P. brandtii occurs in the galls of D. rosae very frequently and sometimes kills the gall wasp. Nevertheless, its impact on the gall-producer is likely to be very small (Stille, 1984). This statement is in contradiction with the findings of Voukassovitch (1928) in Serbia, who raised only $P$. brandtii from the galls of $D$. rosae. For example, Džanokmen (1978) considers P. brandtii a parasitoid of D. rosae larvae, too.

In the Brno region, P. brandtii emerged 2-3 weeks later than D. rosae. Imagos of P. brandtii were emerging from galls brought into the laboratory on 7 April 2015 from 21 April to 27 May while imagos of D. rosae were emerging from 8 April to 17 May. The imagos differ from those of $D$. rosae conspicuously by their morphology and size. Their cranium is $0.50-0.96 \mathrm{~mm}$ (av. $0.80 \mathrm{~mm}$ ) wide, the average body length and width is $2.39 \mathrm{~mm}$ and $0.74 \mathrm{~mm}$, resp. (Figs. 7, 8 and 9, Tab. IX). In the studied region, P. brandtii was found in ca. $10 \%$ of D. rosae galls. This inquiline gall wasp inhabited 0-100 (av. 3.6\%) of the total number of cells (Tab. XIII). Exceptionally (e.g. on the Kamenný vrch Hill in Brno-Pisárky), the galls contained only cells occupied by $P$. brandtii, this indicating that the inquiline may occasionally live as a parasite also in the galls of D. rosae with multiple cells. 
IX: Average cranium width and average length and width of imagos of D. rosae and Periclistus brandtii (1 division =0.0357 $\mathrm{mm}$ ). Brno Region, 2015

\begin{tabular}{|c|c|c|c|c|}
\hline \multirow{2}{*}{ Cranium width } & \multicolumn{2}{|c|}{ D. rosae } & \multicolumn{2}{|c|}{ P. brandtii } \\
\hline & number & average length/width & number & average length/width \\
\hline 15 & - & - & 1 & $40.0 / 13.0$ \\
\hline 16 & - & - & - & - \\
\hline 17 & - & - & 3 & $55.0 / 15.0$ \\
\hline 18 & - & - & 2 & $55.0 / 16.0$ \\
\hline 19 & - & - & 5 & $55.0 / 16.2$ \\
\hline 20 & - & - & 13 & $56.0 / 17.8$ \\
\hline 21 & - & - & 11 & $62.3 / 18.7$ \\
\hline 22 & 1 & $80.0 / 23.0$ & 13 & $61.5 / 19.7$ \\
\hline 23 & 4 & $70.5 / 22.5$ & 17 & $67.9 / 21.3$ \\
\hline 24 & 3 & $76.7 / 21.7$ & 20 & $74.2 / 23.1$ \\
\hline 25 & 1 & $80.0 / 26.0$ & 17 & $78.5 / 23.2$ \\
\hline 26 & 5 & $84.0 / 24.2$ & 6 & $73.3 / 24.2$ \\
\hline 27 & 7 & $87.9 / 26.1$ & 1 & $82.0 / 23.0$ \\
\hline 28 & 9 & $89.4 / 27.0$ & - & - \\
\hline 29 & 5 & $97.0 / 28.4$ & - & - \\
\hline 30 & 25 & $101.3 / 28.4$ & - & - \\
\hline 31 & 20 & $103.5 / 30.8$ & - & - \\
\hline 32 & 30 & $104.2 / 30.4$ & - & - \\
\hline 33 & 27 & $114.3 / 33.1$ & - & - \\
\hline 34 & 32 & $121.1 / 33.8$ & - & - \\
\hline 35 & 19 & $119.5 / 35.0$ & - & - \\
\hline 36 & 2 & $112.5 / 31.5$ & - & - \\
\hline 37 & 2 & $132.5 / 39.0$ & - & - \\
\hline Total & 192 & - & 109 & - \\
\hline Average & 31.5 & $106.5 / 30.8$ & 22.5 & $67.0 / 20.7$ \\
\hline$(\mathrm{mm})$ & 1.12 & $3.80 / 1.10$ & 0.80 & $2.39 / 0.74$ \\
\hline
\end{tabular}

X: Average size of individual developmental stages/instars of D. rosae (1 division =0.0357 mm). Brno region, 2015, 2016

\begin{tabular}{lccc}
\hline \multicolumn{1}{c}{ Stage/instar } & Average cranium width & Average length & Average width \\
\hline Eggs & - & 7.0 & 6.5 \\
$\mathbf{1}^{\text {st }}$ instar larvae (total) & 7.8 & 17.9 & 10.1 \\
- young larvae & 7.1 & 15.9 & 9.0 \\
- growing/grown-up larvae & 9.8 & 25.0 & 14.1 \\
2 $^{\text {nd }}$ instar larvae (total) & 15.3 & 85.8 & 35.8 \\
- young larvae & 15.1 & 55.9 & 25.2 \\
- growing/grown-up larvae & 15.4 & 104.9 & 41.9 \\
$\mathbf{2}^{\text {nd }}$ instar larvae (with eyes) & 15.5 & 135.2 & 48.1 \\
Prepupae & 27.5 & 119.2 & 27.5 \\
Pupae & 33.0 & 112.3 & 41.3 \\
Imagos & 31.5 & 106.5 & 30.8 \\
\hline
\end{tabular}




\section{Mortality}

The galls of $D$. rosae provide to their creators favourable environment, i.e. food and protection from adverse climatic effects such as solar radiation and drying out. However, they protect them only partly against insect parasitoids and various predators. Namely the dense branched outgrowths, which are covered with colourless tacky secretion at the time of the growth of galls, have a protective function. The limited protective effect of the mossy cover of the galls is among other things documented also by the fact that only a few small parasitoid representatives of the order of Hymenoptera are trapped and killed thereby.

According to László and Tóthmérész (2011), only $25 \%$ of imagos of cecidogeneous D. rosae emerge from the galls. The remaining $75 \%$ are parasitoids (46\%) and inquilines with their own parasitoids (29\%). Schröder (1967), Stille (1984) and other authors specified the composition of insect community associated to the galls of $D$. rosae. The parasitisation ranges from 12.5 to $100 \%$ (Rizzo and Massa, 2006). The community of parasitoids and inquilines bound to the galls of D. rosae is relatively well known and similar as in other Diplolepis spp. (Askew et al., 2006). Its species structure is relatively constant from Spain up to central and Eastern Europe (László, 2001).

From a wide range (ca. 30 species) of parasitoids from the order of Hymenoptera, most frequently mentioned in Europe are Orthopelma mediator (Thunb.) (Ichneumonidae), Torymus bedeguaris (L.), Glyphomerus stigma (F.) (Torymidae), Eurytoma rosae Nees (Eurytomidae) and Pteromalus bedeguaris (Thoms.) (Pteromalidae). All these species belong to common inhabitants of the galls of D. rosae in the Brno region. According to Noyes (2011), P. bedeguaris may also infest O. mediator, T. bedeguaris, G. stigma, inquiline P. brandtii and the larvae of other Diplolepis spp. One of common parasitoids of P. brandtii is also E. rosae (Rizzo

XI: Increase in average length and width of cells with intact development of D. rosae (1 division =0.0357 mm). Brno region, 2015, 2016

\begin{tabular}{lcccccc}
\hline \multirow{2}{*}{\multicolumn{1}{c}{ Stage/instar }} & \multicolumn{2}{c}{ Number } & \multicolumn{2}{c}{ Average length } & \multicolumn{2}{c}{ Average width } \\
\cline { 2 - 7 } & $\mathbf{2 0 1 5 / 1 6}$ & total & $\mathbf{2 0 1 5 / 1 6}$ & average & $\mathbf{2 0 1 5 / 1 6}$ & average \\
\hline Eggs & $12 / 12$ & 24 & $7.0 / 7.0$ & 7.0 & $6.5 / 6.5$ & 6.5 \\
$\mathbf{1}^{\text {st }}$ instar larvae & $75 / 33$ & 108 & $17.4 / 16.9$ & 17.2 & $13.2 / 13.3$ & 13.2 \\
$\mathbf{2}^{\text {nd }}$ instar larvae & $290 / 210$ & 500 & $72.2 / 81.3$ & 76.0 & $58.3 / 65.0$ & 61.1 \\
$\mathbf{2}^{\text {nd }}$ instar larvae-grown-up & $98 / 80$ & 178 & $105.0 / 107.8$ & 106.3 & $84.3 / 85.4$ & 84.8 \\
$\mathbf{2}^{\text {nd }}$ instar larvae-with eyes & $91 / 65$ & 156 & $106.2 / 113.3$ & 109.2 & $86.0 / 88.7$ & 87.1 \\
Prepupae & $101 / 131$ & 232 & $106.6 / 109.0$ & 108.0 & $85.5 / 89.7$ & 87.9 \\
Total/average & $667 / 531$ & 1198 & - & - & - & - \\
\hline
\end{tabular}

XII: Average length and width of cells with intact and impaired development of D. rosae (1 division $=0.0357 \mathrm{~mm}$ ). Brno region, October-December 2015, 2016

\begin{tabular}{lcccccc}
\hline \multirow{2}{*}{ Health condition } & \multicolumn{2}{c}{ Number of cells } & \multicolumn{2}{c}{ Average length of cells } & \multicolumn{2}{c}{ Average width of cells } \\
\cline { 2 - 7 } & $\mathbf{2 0 1 5 / 1 6}$ & celkem & $\mathbf{2 0 1 5 / 1 6}$ & průměr & $\mathbf{2 0 1 5 / 1 6}$ & průměr \\
\hline Intact development & $401 / 392$ & 793 & $107.2 / 110.0$ & 108.6 & $86.7 / 89.2$ & 87.9 \\
Parasitoids & $84 / 133$ & 217 & $87.7 / 94.7$ & 92.0 & $70.9 / 75.7$ & 73.8 \\
Natural mortality & $45 / 61$ & 106 & $87.8 / 78.1$ & 82.2 & $71.2 / 62.7$ & 66.3 \\
Inquilines & $28 / 14$ & 42 & $58.9 / 66.1$ & 61.3 & $42.8 / 44.7$ & 43.4 \\
Predators & $-/ 1$ & 1 & $-/ 140.0$ & 140.0 & $-/ 90.0$ & 90.0 \\
Total/average & $558 / 601$ & 1159 & $100.3 / 102.4$ & 101.4 & $80.9 / 82.5$ & 81.7 \\
$(\mathbf{m m})$ & - & - & $3.58 / 3.66$ & 3.62 & $2.89 / 2.95$ & 2.92 \\
\hline
\end{tabular}

XIII: Differences in average length and width of cells with impaired/intact development of D. rosae - see also Tab. XII. Brno region, October-December 2015, 2016

\begin{tabular}{lcccccc}
\hline \multirow{2}{*}{ Health condition } & \multicolumn{2}{c}{ Number of cells (\%) } & \multicolumn{2}{c}{ Average length of cells (\%) } & \multicolumn{2}{c}{ Average width of cells (\%) } \\
\cline { 2 - 7 } & $\mathbf{2 0 1 5 / 1 6}$ & average & $\mathbf{2 0 1 5 / 1 6}$ & average & $\mathbf{2 0 1 5 / 1 6}$ & average \\
\hline Intact development & $71.9 / 65.2$ & 68.4 & $100.0 / 100.0$ & 100.0 & $100.0 / 100.0$ & 100.0 \\
Parasitoids & $15.0 / 22.1$ & 18.7 & $-18.2 / 13.9$ & -15.3 & $-18.2 / 15.1$ & -16.0 \\
Natural mortality & $8.1 / 10.2$ & 9.2 & $-18.1 / 29.0$ & -24.3 & $-17.9 / 29.7$ & -24.6 \\
Inquilines & $5.0 / 2.3$ & 3.6 & $-45.1 / 39.9$ & -43.6 & $-50.6 / 49.9$ & -50.6 \\
Predators & $-/ 0.2$ & 0.1 & $+-/ 27.3$ & +28.9 & $+-/ 0.9$ & +2.4 \\
Total & $100.0 / 100.0$ & 100.0 & - & - & - & - \\
\hline
\end{tabular}


and Massa, 2006). Other species often developing in the galls as parasitoids or hyperparasitoids are Caenacis inflexa (Walk.) (Pteromalidae), Eupelmus urozonus Dalm. (Eupelmidae) and others (Todorov et al., 2012). Apart from T. bedeguaris, G. stigma, E. rosae, P. bedeguaris and E. urozonus, natural enemies of D. rosae in the southern part of the natural range (Turkey) are also Megastigmus rosae Bouček (Torymidae), Aprostocetus eurytomidae (Nees) (Eulophidae), Brachymeria walkeri Dalla Torre (Chalcididae) and Cotesia pieridis (Bouché) (Braconidae) (Bayram, Ülgentürk and Toros, 1998). The galls of $D$. rosae host a number of other species and not all of them are parasitoids of larvae (more rarely of prepupae, pupae and imagos) of gall-producers. Some species parasitize on the inquline P. brandtii; others are hyperparasitoids and/or superparasitoids. Most geographically spread species develop in the galls of several gall wasp species and only very few species specialize for a certain specific host (Nikol'skaja, 1952; Nikol'skaja and Zerova, 1978; Džanokmen, 1978 and others). Some natural enemies (e.g. T. bedeguaris) may efficiently control the population of their host (Guo et al., 2013).

In 2015 and 2016, parasitoids occurred in the Brno region in $0-78 \%$ (av. $15.0 \%$ ) and in $0-87.5 \%$ (av. $22.1 \%$ ) of cells, respectively (Tabs. XII and XIII). Spectrum and dominance of individual species were not examined. Surprising is a relatively low total proportion of cells with the larvae of D. rosae killed by parasitoids (18.7\%) and a high share of cells with the vital larvae (68.4\%). Average mortality values presented in the tables relate to October-December 2015 and 2016. During winter and spring, the mortality of $D$. rosae further increased, namely due to the pecking up of the galls by birds, rarely due to small rodents eating out the galls etc. The process of gall pecking up starts usually in the first half of January and culminates towards the end of spring. Pecked up is usually up to $75 \%$ (av. 30\%) of gall contents. On some sites (e.g. on the Palacký vrch Hill in Brno-Žabovřesky and in Brno-Černá Pole), birds caused damage up to $50 \%$ of galls. Critical drought and tropical heat waves during the growing season of 2015 caused local drying out of galls and subsequent dying of larvae in the Pozořice forest district. However, total increase of mortality was not recorded in the Brno region. Taking into account all mortality factors, we can state that in the studied region, D. rosae completes successfully its development on average in $50 \%$ of cells.

Cavities deserted by emerged D. rosae, P. brandtii and parasitoids often become inhabited by other insect species (e.g. some representatives of Tenthredinidae, Gryllidae, Chacidoidea and Ichneumonoidea), which find occasional hideaway or place for their own development therein (Hintze-Podufal and Thiele, 1988). Accidental inhabitants of galls are Cladius pectinicornis (Geoffr. in Fourcr.) (Tenthredinidae), Colpoclypeus florus (Walk.) (Eulophidae) (Todorov et al., 2012) and Bethylus cephalotes (Foerst.) (Bethylidae) (Blair, 1944). In the deserted galls of D. rosae in the Brno region, we sometimes found larvae from the family of Tenthredinidae, Ichneumonidae, cocoons with the eggs and nymphs of Araneida, eggs, larvae and imagos of Leptothorax Mayr (Formicidae), nymphs and imagos of Dermaptera, larvae of Neuroptera and others. Gall tissues were often infested by the parasitic fungus Phragmidium mucronatum (Pers.) Schl. (syn. P. subcorticum/Schr./Wint.).

\section{Economic Importance}

Gall wasp D. rosae occurs in Europe primarily on wild Rosa spp. On cultivated roses, it was observed only sporadically. In terms of forestry, it is a species of no importance. Nevertheless, with respect to its generally abundant occurrence, extensive natural range, size and prominence of its galls, numerous authors consider the species a pest (Kieffer, 1914; Lüstner, 1931; Dmitriev, 1975; Kovalev, 1981; Bayram, Ülgentürk and Toros, 1998; Herting, undated, and others). Economic losses are recorded e.g. in Canada (Gibson, 1935) and in China (Guo et al., 2013). This is why Shorthouse (2015) warns the rose growers about possible passive spreading of the pest by means of galls over long distances.

The galls of D. rosae weaken their host plants physiologically, malforming the shape of their low-diameter shoots and causing their dwarfing or even dieback. While pleurocecidia suppress the growth of shoots, acrocecidia terminate the length growth and often induce branching. Therefore, for example Schröder (1967) and Syrett (1990) consider D. rosae a promising potential killer of weed Rosa rubiginosa in New Zealand. The successful fight with the wild rabbit, which formerly devastated young plants and shoots of this rose species, led to harmful spreading of the rose and to searching efficient methods of its environment-friendly control. The authors recommend supporting the efficiency of D. rosae introduction with other prominent natural under-bark and leaf-eating enemies of the rose.

As a rule, D. rosae is however taken for a species rather interesting than harmful because the galls are created most frequently on the leaves by contrast to D. fructuum (Rübs.), which for example in Turkey caused serious damage on the fruits (rose hips) (Güçlü et al., 2008). In case of need, it can be best controlled after the end of the growing season by removing the galls and their subsequent burning.

In this context, we cannot leave out of consideration some allegedly curative properties of the galls such as sleep inducing capacity that was attributed to them in the past. To cure insomnia, the galls were placed under sleeping pillow. For their astringent effects, they were used to cure diarrhoea, gastritis and enteritis. They were advised at inflammations of oral mucosa and for elimination of toothache. Powder made of galls blended with honey and applied on the head skin was believed to prevent alopecia. As a supposed cure, the galls were used in veterinary medicine and in the medication of honeybee diseases. 


\section{CONCLUSION}

Thanks to the noticeable and abundant galls, Diplolepis rosae is the most popular representative of the cecidogeneous genus of Diplolepis spp. on the Rosa spp. The objective of the presented study was to examine the species' hitherto little known preimaginal development and gall creation. The research was conducted from June to December 2015 and 2016 in four forest districts in the surroundings of Brno. Galls sampled at week intervals from R. canina were microscopically analyzed in the laboratory. Our findings are as follows:

Diplolepis rosae hibernates in the Brno region at a stage of grown-up larvae and prepupae. In the winter period of 2015/2016 and 2016/2017, 30\% (53\%) of larvae and 70\% (47\%) of prepupae hibernated, respectively. The extremely warm and dry growing season of 2015 obviously accelerated the development significantly. In 2016 and 2017, prepupae were pupating from 15 March to 15 July and from 20 March to 20 July, respectively. Imagos were emerging in the period from April to July, i.e. 4 months. Individuals of both sexes were hatching at the same time and the share of males in the populations was $0-9 \%$ (av. $4.5 \%$ ).

At average fecundity of 500 eggs, females can lay egg on nine different sites. However, the actual number of galls is lower than the fitness of females due to the mortality of eggs. The galls begin to show at the end of May and in early June; they consist of 1-225 (av. 54) cells. Small galls (up to $20 \mathrm{~mm}$ ) are usually compact; larger galls (beyond $20 \mathrm{~mm}$ ) consist as a rule of 2-20 (av. 7) \pm together grown parts. The parts are also connected by numerous outgrowths, which give the galls mossy appearance. A gall of average size ( $\emptyset 32 \mathrm{~mm}$ ) features about 700 outgrowths of 3-22 $\mathrm{mm}$ (av. $13.1 \mathrm{~mm}$ ) in length. At the gall apex and on its sides, the outgrowths are longer and branched; at the gall base, they are short and not branching.

The growth of galls is most vigorous in June and July, and gradually ceases in October. In the extremely warm and dry year 2015, the galls were on average $35.2 \mathrm{~mm}$ high and $44.4 \mathrm{~mm}$ wide. In the climatically more favourable year 2016, the galls were on average $45.5 \mathrm{~mm}$ high and $49.9 \mathrm{~mm}$ wide. On average $63.5 \%$ of the galls were localized on the sides of shoots and $36.5 \%$ on the apex. Flushing or freshly broken leaves were infested in $85.1 \%$ while flowers and fruits (rose hips) were infested in $14.9 \%$. The largest and most abundant galls were found on shoots with the highest annual increment.

In the Brno region, eggs were occurring from late May to the end of July; $1^{\text {st }}$ and $2^{\text {nd }}$ instar larvae were occurring from June to August and from the beginning of July to the end of October, resp. Some larvae moulted towards the end of the growing season. Hibernating were $47-70 \%$ of prepupae and $30-53 \%$ of grown-up larvae in the galls.

The $1^{\text {st }}$ instar larvae had the cranium width ranging from 0.14 to $0.43 \mathrm{~mm}$. During the growth, it became enlarged on average from 0.25 to $0.35 \mathrm{~mm}$ (by $38 \%$ ). In 2015 , the grown-up larvae of the $1^{\text {st }}$ instar were by $20.2 \%$ shorter and by $8.6 \%$ narrower than in 2016 . The $2^{\text {nd }}$ instar larvae had the cranium width ranging from 0.50 to $0.68 \mathrm{~mm}$. During the growth, it became enlarged on average from 0.54 to $0.55 \mathrm{~mm}$ (by $1.9 \%$ ). Weather differences had no influence on the width of cranium. In 2015 , the average length and width of the larvae was $2.8 \mathrm{~mm}$ and $1.2 \mathrm{~mm}$, resp. In 2016, the average length and width of the larvae was $3.3 \mathrm{~mm}$ (by 15.6\% longer) and $1.36 \mathrm{~mm}$ (by 13.7\% wider), resp. The tropical heat and drought in the growing season of 2015 reflected in smaller dimensions of the larvae.

After the end of feeding, the cells are on average $3.9 \mathrm{~mm}$ long and $3.1 \mathrm{~mm}$ wide. In the climatically milder year 2016, the cells were larger than in the abnormal year 2015. As compared with the cells with the intact development of the gall wasp, the cells with parasitoids are on average by $15 \%$ smaller and the cells with the gall wasp larvae killed by natural factors (primarily drought) are smaller by $24.5 \%$. The smallest cells (by $43.6 \%$ shorter and by $50.6 \%$ narrower) are those with the larvae of inquiline Periclistus brandtii.

Imagos of P.brandtii emerged in the Brno region by 2-3 weeks later than imagos of D. rosae. The inquiline occurred on average in $10 \%$ of galls in $0-100 \%$ (av. 3.6\%) of cells. Nonetheless, it participates on the mortality of D. rosae only occasionally and at a low extent. In 2015 and 2016, parasitoids occupied 0-78\% (av. 15.0\%) and 0-87.5\% (av. 22.1\%) of D. rosae cells, respectively. From the first half of January to the end of spring, birds caused damage up to $50 \%$ (av. $24 \%$ ) of galls. Pecked out was at all times only a part (max. 2/3) of the gall contents.

\section{REFERENCES}

ADLER, H. 1877. Beiträge zur Naturgeschichte der Cynipiden. Deutsche entomologische Zeitschrift, 21: 209-248. ASKEW, R. R. 1960. Some observations on Diplolepis rosae (L.) (Hym., Cynipidae) and its parasites. Entomologist's Monthly Magazine, 95: 191-192.

ASKEW, R. R., SADEGHI, S. E. and TAVAKOLI, M. 2006. Chalcidoidea (Hym.) in galls of Diplolepis mayri (Schlechtendal) (Hym., Cynipidae) in Iran, with the description of a new species of Pseudotorymus Masi (Hym., Torymidae). Entomologist's Monthly Magazine, 142(1700/2): 1-6. 
BAYRAM, Ş., ÜLGENTÜRK, S. and TOROS, S. 1998. Research on the insects causing galls on dog rose (Rosa spp.) and their parasitoids in Ankara province. Türkiye Entomoloji Dergisi, 22: 259-268.

BLAIR, K. G. 1943. On the rose bedeguar gall and its inhabitants. Entomologist's Monthly Magazine, 79: 231-233.

BLAIR, K. G. 1944. A note on the economy of the rose bedeguar gall, Rhodites rosae L. Proceedings and transactions of the South London Entomological and Natural History Society, 1943-44: 55-59.

BLAIR, K. G. 1945. Notes on the economy of the rose-galls formed by Rhodites (Hymenoptera: Cynipidae). Proceedings of the Royal Entomological Society of London (A), 20: 26-31.

BLAIR, K. G. 1951. Eupelmus urozonus Dahlb. (Hym., Chalcididae) in galls of Rhodites rosae L. (Hym., Cynipidae). Entomologist's Monthly Magazine, 87: 174-175.

BLOMMERS, L. H. M. 2008. Pemphredon austriaca (Hymenoptera: Grabronidae) an various other insect species as inhabitants of deserted galls. Entomologische Berichten, 68: 170-174.

BOWDREY, J. 2007. A first British record of the gall of Diplolepis rosae L. (Hymenoptera: Cynipidae) on the introduced redleaved rose (Rosa ferruginea Vill.). Cecidology, 22: 18.

BOYADZHIEV, P. S. and TODOROV, I. A. 2013. A new distinctive species of the genus. Revue Suisse de Zoologie, 120: 346-356.

BRONNER, R. 1985. Anatomy of the ovipositor and oviposition behaviour of the gall wasp Diplolepis rosae (Hymenoptera, Cynipidae). The Canadian Entomologist, 117: 849-858.

CALLAN, E. M. 1940. On the occurrence of males of Rhodites rosae L. (Hymenoptera: Cynipidae). Proceedings of the Royal Entomological Society of London (A), 15: 21-26.

CHIRECEANU, C., CHIRILOAIE, A., TEODORU, A. and SIVU, C. 2015. Contribution to knowledge of the gall insects and mites associated with plants in southern Romania. Scientific Papers, Series B, 59: 27-36.

CZECZUGA, B., CZECZUGA-SEMENIUK, E. and SEMENIUK, A. 2008. Canthaxanthin- a predominant carotenoid in galls produced by Rhodites rosae (Hymenoptera: Cynipidae). Current Topics in Plant Biology, 9: 129-133.

DALLA TORRE de, C. G. 1893. Catalogus Hymenopterorum. Vol. II. Cynipidae. Lipsiae, Sumptibus Guilelmi Engelmann, pp. 1-140.

DALLA TORRE von, K. W. and KIEFFER, J. J. 1910. Hymenoptera, Cynipidae. Das Tierreich, 24. Lieferung. Berlin: Verlag von R. Friedländer und Sohn.

DARBOUX, G. and HOUARD, C. 1901. Catalogue systématique des zoocécidies de l'Europe et du Bassin Méditerranéen. Paris: Laboratoire d'évolution des ètres organisés, pp. 1-544.

DMITRIEV, G. V. 1975. Vrediteli parkovych nasaždenij. In: VASILJEV, V. P. (Ed.). Vrediteli sel'sko-chozjajstvennych kulturi lesnych nasaždenij. Tom III. Kiev: Izdatel'stvo Urožaj, pp. 343-367.

DOĞANLAR, M. 1984. Notes on Chalcidoidea of Turkey. I. Chalcididae, Eurytomidae, Torymidae, Ormyridae, Perilampidae, Eucharitidae. Türkiye Bitki Koruma Dergisi, 8: 151-158.

DŽANOKMEN, K. A. 1978. 5. Sem. Pteromalidae-Pteromalidy. In: MEDVEDEV, G. S. (Ed.). Opredelitel' nasekomych evropejskoj časti SSSR. Tom III. Vtoraja čast ${ }^{2}$. Leningrad,: Izdatel'stvo Nauka, pp. 57-228.

ELLIS, H. A. 2004. Some inhabitants of Diplolepis rosae (L.) (Bedeguar) galls in south-east Northumberland. Vasculum, 89: 2-7.

ESCHERICH, K. 1942. Die Forstinsekten Mitteleuropas. 5. Band. Berlin: Verlag von P. Parey, pp. 1-746.

FARAHBAKHSH, G. 1961. Checklist of important insects and other enemies of plants of agriculture products in Iran. Tehran: Ministry of Agriculture and Natural Resources, Extension Service, pp. 1-44.

FERRARI, J., KRUESS, A. and TSCHARNTKE, T. 1997. Effects of fragmentation of wild roses on their insect communities. Mitteilungen der Deutschen Gesellschaft für Allgemeine und Angewandte Entomologie, 11: 87-90.

GAUSS, R. 1982. Familienreihe Cynipoidea. In: SCHWENKE, W. (Ed.), Die Forstschädlinge Europas. 4. Band. Hautflügler und Zweiflügler. Hamburg und Berlin: Verlag P. Parey, pp. 234-254.

GIBSON, A. 1935. Insect pests of the rose and their cotrol. Bulletin. Department of Agriculture, Canada, 17: 52-55. GRIGOROV, S. 1962. Contribution to the entomofauna of Bulgaria. Plant protection, 10: 48-54.

GUO, R., WU, B. M., ZHANG, W. L., WANG, Y. Q. and WANG, Y. P. 2013. First discovery of an invasive gall-former insect pest, Diplolepis rosae, in China. Chinese Journal of Applied Entomology, 50: 500-504.

GUSEV, V. I. and RIMSKIJ-KORSAKOV, M. N. 1953. Klíč určováníškiudcu lesních a okrasných stromů a keřu evropské části SSSR. Praha: Státní zemědělské nakladatelství, pp. 1-535.

GÜÇLÜ, S., HAYAT, R., SHORTHOUSE, J. D. and TOZLU, G. 2008. Gall-inducing wasps of the genus Diplolepis (Hymenoptera: Cynipidae) on shrub roses of Turkey. Proceedings of the Entomological Society of Washington, 110: 204-217.

HERTING, B. Undated. Rosa rubiginosa project. European investigations for New Zealand. Lepidoptera, Hymenoptera and Diptera attacking Rosa in Europe. Report. Commonwealth Institute Biology Control, European Stat., pp. 1-18.

HESAMI, S., BEHZADI, M. R., EBRAHIMI, E., MIRESMAILI, S. S. and DOĞANLAR, M. 2008. Report of Torymus lapsanae (Hym.: Torymidae), a parazitoid of Diplolepis rosae (Hym.: Cynipidae) from Iran. Journal of Entomological Society of Iran, 27: 17-18.

HINTZE-PODUFAL, C. and THIELE, C. 1988. Untersuchungen zur Mikrofauna des Rosenbedeguars. Mitteilungen der Deutschen Gesellschaft für Allgemeine und Angewandte Entomologie, 6: 537-541.

HOLÝ, K. 2011. Žlabatky (Hymenoptera: Cynipidae) Národního parku Podyjí. Thayensia (Znojmo), 8: 93-100. 
JUDD, W. W. 1959. Hymenoptera reared from the mossy rose gall caused by Diplolepis rosae (L.) (Hymenoptera: Cynipidae). The Canadian Entomologist, 91: 727-730.

KATILMIŞ, Y. and KIYAK, S. 2010. Distribution, phenology and effects of Diplolepis spp. (Hymenoptera: Cynipidae) on Rosa canina in the inland Western Anatolian. Journal of Entomological Research Society, 12: 31-36.

KIEFFER, J.J. 1914. Die Gallwespen (Cynipiden) Mitteleuropas insbesondere Deutschlands. In: SCHRÖDER, C. (Ed.). Die Insekten Mitteleuropas insbesondere Deutschlands. Band III. Hymenopteren. Dritter Teil. Stuttgart: Franckh'sche Verlagshandlung, pp. 1-94.

KOHNEN, A., WISSEMANN, V. and BRANDL, R. 2011. No host-associated differentiation in the gall wasp Diplolepis rosae (Hymenoptera: Cynipidae) on three dog rose species. Biological Journal of the Linnean Society, 102: 369-377.

KOHNEN, A., RICHTER, I. and BRANDL, R. 2012. No concordant phylogeographies of the rose gall wasp Diplolepis rosae (Hymenoptera, Cynipidae) and two associated parasitoids across Europe. Public Library of Sciences ONE, 7: e47156.

KOVALEV, O. V. 1981. Nads. Cynipoidea-cinipoidy. In: NARČUK, E. P. and V. A. TRJAPICYN, V. A. (Eds.). Nasekomye $i$ klešči-vrediteli sel'skochozjajstvennych kultur. Tom IV. Pererpončatokrylye $i$ dvukrylye. Leningrad: Izdatel'stvo „Nauka“, pp. 34-37.

LÁSZLÓ, Z. 2001. The parasitic complex of Diplolepis rosae (Linnaeus, 1758) (Hymenoptera: Cynipidae): influencing factors and interspecific relationship. Entomologica romanica, 6: 133-140.

LÁSZLÓ, Z. and TÓTHMÉRÉSZ, B. 2006. Inquiline effects on a multilocular gall community. Acta Zoologica Academiae Scientiarum Hungaricae, 52: 373-383.

LÁSZLÓ, Z. and TÓTHMÊRÉSZ, B. 2007. Spatial pattern an parasitisation of rose shrubs (Rosa spp.) by Diplolepis rosae. Természetvédelmi Kózlemények, 13:233-240.

LÁSZLÓ,Z. and TÓTHMÉRÉSZ, B. 2008. Optimal clutch size of the gall wasps Diplolepis rosae (Hymenoptera: Cynipidae). Entomologica Fennica, 19: 168-175.

LÁSZLÓ,Z. and TÓTHMÉRÉSZ, B. 2011. Parasitoids of the bedeguar gall (Diplolepis rosae): effect of host scale on density and prevalence. Acta Zoologica Academiae Scientiarum Hungaricae, 57: 219-232.

LÁSZLÓ, Z. and TÓTHMÉRÉSZ, B. 2012. Local and landscape-scale effects on multiparasitoid coexistence. Természetvédelmi Kózlemények, 18: 305-314.

LÁSZLÓ,Z. and TÓTHMÉRÉSZ, B. 2013a. Landscape and local effects on multiparasitoid coexistence. Insect Conservation and Diversity, 6: 354-363.

LÁSZLÓ, Z. and TÓTHMÉRÉSZ, B. 2013b. The enemy hypothesis: correlates of gall morphology with parasitoid attack rates in two closely related rose cynipid galls. Bulletin of Entomological Research, 103: 326-335.

LÂSZLÓ, Z., RÁKOSY, L. and TÓTHMÉRÉSZ, B. 2014. Landscape and local variables benefit rare species and common ones differently. Journal of Insect Conservation, 18: 1203-1213.

LIU, D., ZHANG, W. L. and XIAO, H. 2012. A new Chinese record species Torymus bedeguaris (Hymenoptera, Torymidae). Acta Zootaxonomica Sinica, 37: 907-911.

LÜSTNER, G. 1931. Die wichtigsten tierischen Schädlinge der Rosen und ihre Bekämpfung. Flugblatt. Biologische Reichanstalt für Land-und Forstwirtschaft, 115-116: 8.

MAGNUS, W. 1914. Die Entstehung der Pflanzengallen verursacht durch Hymenopteren. Jena: G. Fischer, pp. $1-160$.

METE, Ö. and MERGEN, Y. O. 2016. The community members associated with rose gall wasp Diplolepis fructuum (Rübsaamen, 1895) (Hymenoptera: Cynipidae) in Tokat Province of Turkey. Turkish Journal of Zoology, 40: 411-416.

MIKULA, P. 1989. Cynipoidea. In: ŠEDIVÝ, J. (Ed.). Enumeratio insectorum Bohemoslovakiae, III (Hymenoptera). Acta faunistica entomologica Musei Nationalis Pragae, 19: 129-132.

MILLER, F. 1956. Zemédèlská entomologie. Praha: Nakladatelství Československé akademie věd, pp. 1-1056.

NIENHAUS, F., BUTIN, H. and BÖHMER, B. 1992. Farbatlas Gehölzkrankheiten. Ziersträucher und Parkbäume. Stuttgart: Verlag Eugen Ulmer, pp. 1-287.

NIEVES ALDREY, J. L. 1981. Datos sobre Diplolepis rosae (L.) (Hym., Cynipidae) y sus himenópteros parásitos en Salamanca. Boletín de la Asociación Española de Entomológia, 4: 107-113.

NIEVES ALDREY, J. L., VÅRDAL, H. and RONQUIST, F. 2005. Comparative morphology of terminal-instar larvae of Cynipoidea: phylogenetic implication. Zoologica Scripta, 34: 15-36.

NIKOLSKAJA, M. N. 1952. Chal'cidy fauny SSSR (Chalcidoidea). Moskva, Leningrad: Izdatel'stvo Akademii Nauk SSSR: 1-575.

NIKOLSKAJA,M.N. andZEROVA,M.D. 1978.9.Sem. Torymidae (Callimomidae)-torymidy.In:MEDVEDEV, G. S. (Ed.). Opredelitel' nasekomych evropejskoj časti SSSR. Tom III. Vtoraja čast'. Leningrad: Izdatel'stvo „Nauka“, pp. 358-374.

NORDLANDER, G. 1973. Parasitic wasps in galls of Diplolepis rosae (L.) and D. mayri Schlechtd. (Hymenoptera: Cynipidae) (Hym.: Ichneumonoidea, Chalcidoidea, Cynipoidea). Entomologisk Tidskrift, 94: 148-176.

NOYES, J. S. 2011. Universal Chalcidoidea Database. Natural History Museum. Available at: http://www.nhm. ac.uk/chalcidoids [Accessed: 2018, July 15]. 
O'CONNOR, J. P. 2004. Eriophyes padi (Nalepa) (Eriophyoidea) new to Ireland with notes on other galls. Cecidology, 19: 3-5.

PLANTARD, O., RASPLUS, J. Y., MONDOR, G., LE CLAINCHE, I. and SOLIGNAC, M. 1999. Distribution and phylogeny of Wolbachia inducing thelytoky in Rhoditini and 'Aylacini' (Hymenoptera: Cynipidae). Insect Molecular Biology, 8: 185-191.

RANDOLPH, S. 2005. The natural history of the Rose Bedeguargall and its insect community. British Plant Gall Society, pp. 1-92.

REDFERN, M. 1997. Plant galls: an intimate association between animals and plants. Antenna (London), 21: $55-63$.

RITCHIE, A.J. andPETERS, T. M. 1981. The external morphology of Diplolepis rosae (Hymenoptera: Cynipidae, Cynipinae). Annals of the Entomological Society of America, 74: 191-199.

RIZZO, M. C. and MASSA, B. 2006. Parasitism and sex ratio of the bedeguar wasp Diplolepis rosae (L.) (Hymenoptera: Cynipidae) in Sicily (Italy). Journal of Hymenoptera Research, 15: 277-285.

RONQUIST, F. 1999. Phylogeny, classification and evolution of the Cynipoidea. Zoologica Scripta, 28: 139-164. SCHAEFFER, P. and MEYER, J. 1963. Observation sur l'origine et le mode de croissance des émergences de la galle de Rhodites rosae L. sur Rosa canina L. Marcellia, 31: 261-279.

SCHILTHUIZEN, M. and STOUTHAMER, R. 1998. Distribution of Wolbachia among the guild associated with the parthenogenetic gall wasp Diplolepis rosae. Heredity, 81: 270-274.

SCHIMITSCHEK, E. 1944. Forstinsekten der Türkei und ihre Umwelt. Amsterdam, Berlin, Wien: Volk und Reich, Verlag Prag, pp. 1-371.

SCHRÖDER, D. 1967. Diplolepis (= Rhodites) rosae (L.) (Hym.: Cynipidae) and a review of its parasite complex in Europe. Technical Bulletin of the Commonwealth Institute of Biological Control, 9: 93-131.

SEDLAG, U. et al. 1986. Insekten Mitteleuropas. Leipzig, Radebeul: Neumann Verlag, pp. 1-408.

SHOJAI, M. 1998. Entomology (ethology, social life and natural enemies) (biological control). Vol. III. $3^{\text {rd }}$ Edition. Tehran University Publication, pp. 1-550.

SHORTHOUSE, J. D. 1998. Role of Periclistus (Hymenoptera: Cynipidae) inquilines in leaf galls of Diplolepis (Hymenoptera: Cynipidae) on wild roses in Canada. 61-81 pp. In: G. CSÓKA, G, MATTSON, W. J., STONE, G. N. and PRICE, P. W. (Eds.). The biology of gall-inducing arthropods. General Technical Report NC-199. St. Paul, Minnesota (U. S. A.): U. S. Department of Agriculture, Forest Service, North Central Research Station, pp. 1-329.

SHORTHOUSE, J. D. 2001. Galls induced by cynipid wasps of the genus Diplolepis (Cynipidae, Hymenoptera) on cultivated shrub roses in Canada. Acta Horticulturae, 547: 83-92.

SLIVA, M. D. and SHORTHOUSE, J. D. 2006. Comparison of the development of stem galls induced by Aulacidea hieracii (Hymenoptera: Cynipidae) on hawkweed and by Diplolepis spinosa (Hymenoptera: Cynipidae) on rose. Canadian Journal of Botany, 84: 1052-1074.

SOLYOM, K. 2015. Bird predation on Rose bedeguar gall (Diplolepis rosae). Természetvédelmi Kózlemények, 21: 271-280.

STILLE, B. 1984. The effect of hostplant and parasitoids on the reproductive succes of the parthenogenetic gall wasp Diplolepis rosae (Hymenoptera: Cynipidae). Oecologia, 63: 364-369.

STILLE, B. and DÄVRING, L. 1980. Meiosis and reproductive strategy in the parthenogenetic gall wasp Diplolepis rosae (L.) (Hymenoptera, Cynipidae). Hereditas, 92: 353-362.

SYRETT, P. 1990. Prospects for the biological control of Rosa rubiginosa (Sweet Brier) in New Zealand. Plant Protection Quarterly, 5: 18-22.

TODOROV, I., STOJANOVA, A., PARVANOV, D. and BOYADZHIEV, P. 2012. Studies on the gall community of Diplolepis rosae (Hymenoptera: Cynipidae) in Vitosha Mountain, Bulgaria. Acta Zoologica Bulgarica, 4: 27-37.

TUDOR, C. and CARUNTU, V. 1980. On some host-parasite relationships on the Cynipinae of the southeast of the country. Studii si Cercetari de Biologie. Biologie Animale, 32: 171-176.

Van MEER, M. M. M., Van KAN, F. J. P. M., BREEUWER, J. A. J. and STOUTHAMER, R. 1995. Identification of symbionts associated with parthenogenesis in Encarsia formosa (Hymenoptera: Aphelinidae) and Diplolepis rosae (Hymenoptera: Cynipidae). Proceedings of the Experimental and Applied Entomology, N. E. V. Amsterdam, 6: 81-86.

VÅRDAL, H., SAHLÉN, G. and RONQUIST, F. 2003. Morphology and evolution of the cynipoid egg (Hymenoptera). Zoological Journal of the Linnean Society, 139: 247-260.

VOUKASSOVITCH, P. 1928. Observation biologiques sur Rhodites rosae L. et ses parasites. Compte rendu des séances de la Sociétéde biologie, 98: 1148-1150.

VYRŽIKOVSKAJA, A. V. 1963. New gall wasps (Hymenoptera, Cynipidae) from dog-rose in Central Asia and Kazakhstan. Entomologičeskoe Obozrenie, 42: 651-659.

WELD, L. H. 1926. Field notes on gall-inhabiting cynipid wasps with description of new species. Proceedings of the United States National Museum, 68: 1-131.

WIEBES-RIJKS, A. A. and SHORTHOUSE, J. D. 1992. Ecological relationships of insects inhabiting cynipid galls. In: SHORTHOUSE, J. D. and ROHFRITSCH, O. (Eds.). Biology of Insect-Induced Galls. New York, USA: Oxford University Press, pp. 238-257. 
WILLIAMS, R. and RANDOLPH, S. 2002. Insect and invertebrate group the rose bedeguar project: rearing and recognising inhabitants. Cecidology, 17: 17-24.

WILLIAMS, J. B., SHORTHOUSE, J. D. and LEE, R. E. JR. 2003. Deleterious effects of mild simulated overwintering temperatures on survival and potential fecundity of rose-galling Diplolepis wasps (Hymenoptera: Cynipidae). Journal of Experimental Zoology, 298: 23-31.

YASUMATSU, K. and TAKETANI, A. 1967. Some remarks on the commonly known species of the genus Diplolepis Geoffroy in Japan. Esakia, 6: 77-86.

Jaroslav Urban: urbanj@mendelu.cz 